\title{
IKK- $\beta$ mediates hydrogen peroxide induced cell death through p85 S6K1
}

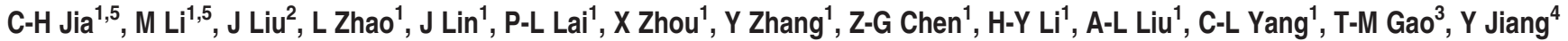 \\ and X-C Bai ${ }^{* 1}$
}

The $\mid \kappa B$ kinase (IKK)/NF- $\kappa$ B pathway has been shown to be a major regulator in cell survival. However, the mechanisms through which IKK mediates cell death are not clear. In this study, we showed that IKK- $\beta$ contributed to hydrogen peroxide $\left(\mathrm{H}_{2} \mathrm{O}_{2}\right)$ induced cell death independent of the NF- $\kappa$ B pathway. Our results demonstrated that the pro-death function of IKK- $\beta$ under oxidative stress was mediated by p85 S6K1 (S6 kinase 1), but not p70 S6K1 through a rapamycin-insensitive and mammalian target of rapamycin complex 1 kinase-independent mechanism. We found that IKK- $\beta$ associated with p85, but not p70 S6K1, which was required for $\mathrm{H}_{2} \mathrm{O}_{2}$-induced activation of $\mathrm{p} 85 \mathrm{~S} 6 \mathrm{~K} 1$. IKK- $\beta$ and p85 S6K1 contributed to $\mathrm{H}_{2} \mathrm{O}_{2}$-induced phosphorylation of Mdm2 (S166) and p53 accumulation. p85 S6K1 is critical for IKK- $\beta$-mediated cell death. Thus, these findings established a novel oxidative stress-responsive pathway that involves IKK- $\beta$, p85 S6K1 and Mdm2, which is response for $\mathrm{H}_{2} \mathrm{O}_{2}$-induced cell death. Our results have important implications for IKK- $\beta$ and p85 S6K1 as potential targets for the prevention of diseases involved in oxidative stress-induced aberrant cell death.

Cell Death and Differentiation (2013) 20, 248-258; doi:10.1038/cdd.2012.115; published online 7 September 2012

Reactive oxygen species (ROS), such as hydrogen peroxide $\left(\mathrm{H}_{2} \mathrm{O}_{2}\right)$, are generated in cells as a consequence of oxidative metabolism. Although low levels of ROS are usually detoxified quickly by antioxidant enzymes, an excessive accumulation of ROS may result in oxidative stress. High and/or persistent levels of oxidative stress represent a major cause of cellular damage and aberrant death in a plethora of pathological conditions during the initiation and progression of a plethora of pathological conditions, including neurodegenerative diseases, cancer, autoimmune and the ageing process. ${ }^{1}$ While ROS may trigger cell death through multiple mechanisms, ${ }^{2}$ recent studies have established the nuclear factor $-\kappa \mathrm{B}(\mathrm{NF}-\kappa \mathrm{B})$ pathway as a critical signaling pathway in mediating the action of ROS in cell survival/cell death. ${ }^{3}$

The NF- $\kappa$ B protein is a transcription factor composed of two subunits, and in many cell types the predominant form is the p65/p50 heterodimer complex. Inactive NF- $\kappa \mathrm{B}$ exists in the cytoplasm in association with an inhibitor protein, $\mathrm{I} \kappa \mathrm{B} \alpha$. Canonical activation of $\mathrm{NF}-\kappa \mathrm{B}$ requires signaling events that activate $\mathrm{I}_{\kappa} \mathrm{B}$ kinase (IKK) complexes, which are composed of catalytic subunits (IKK- $\alpha / \mathrm{IKK}-1$ and IKK- $\beta / \mathrm{IKK}-2)$ and a regulatory subunit IKK- $\gamma / \mathrm{NEMO}$ (NF- $\kappa \mathrm{B}$ essential modulator). An activated IKK phosphorylates $\mathrm{I}_{\kappa} \mathrm{B}-\alpha$ and releases $\mathrm{NF}-\kappa \mathrm{B}$ for activation. ${ }^{4}$ Activation of IKK/NF- $\kappa$ B pathway by exogenous $\mathrm{H}_{2} \mathrm{O}_{2}$ has been found to be cell type-dependent. In some cell lines, $\mathrm{H}_{2} \mathrm{O}_{2}$ activates the pathway, ${ }^{5-8}$ whereas in other cells, it has an opposite effect. ${ }^{9}$ The pro-survival role of NF- $\kappa \mathrm{B}$ pathway has been extensively characterized. ${ }^{3}$ However, in some cell lines, NF- $\kappa$ B has been shown to possess pro-cell death function. ${ }^{10,11} \mathrm{~A}$ recent study demonstrated that NF- $\kappa \mathrm{B}$ sensitized MEF cells to oxidative stress via caspaseindependent pathway. ${ }^{12}$ However, the pro-death role of IKK under oxidative stress has not been reported, and the mechanisms by which IKK/NF- $\kappa B$ pathway promotes cell death remain to be defined.

The mammalian target of rapamycin (mTOR) is a serine/ threonine kinase and the catalytic subunit of two distinct complexes called mammalian target of rapamycin complex (mTORC)1 and mTORC2. Macrolides rapamycin allosterically inhibits the activity of mTORC1. The mTOR signaling pathway serves as a central regulator of cell metabolism, growth, proliferation, ageing and survival by integrating both intracellular and extracellular signals such as growth factors, nutrients, energy and stresses. ${ }^{13}$

One of the key effectors of the mTORC1 signaling pathway is S6 kinase 1 (S6K1), which has important roles in cell growth, cell survival and lifespan. ${ }^{14,15}$ S6K1 exists in two isoforms, p70 and p85. The p85 form differs from p70 by an $\mathrm{N}$-terminal addition of 23 amino acids, which has been shown to function as a nuclear localization signal for targeting p85

\footnotetext{
${ }^{1}$ Department of Cell Biology, Southern Medical University, Guangzhou 510515, China; ${ }^{2}$ Department of Urology, Guangzhou General Hospital of Guangzhou Command, Guangzhou 510010, China; ${ }^{3}$ Department of Anatomy and Neurobiology, Southern Medical University, Guangzhou 510515, China and ${ }^{4}$ Department of Chemical Biology and Pharmacology, University of Pittsburgh School of Medicine, Pittsburgh, PA 15213, USA

${ }^{*}$ Corresponding author: X-C Bai, Department of Cell Biology, Southern Medical University, Guangzhou 510515, China. Tel: +86 2061648724 ; Fax: + 8620 61648208; E-mail: baixc15@smu.edu.cn

${ }^{5}$ These authors contributed equally to this work.

Keywords: IKK- $\beta$; hydrogen peroxide; S6K1; mammalian target of rapamycin

Abbreviations: IKK, I $\mathrm{KB}$ kinase; mTORC1, mammalian target of rapamycin complex 1; Mdm2, murine double minute-2; ROS, reactive oxygen species; $I_{\kappa} B$, inhibitor of $\kappa \mathrm{B}$; NF- $\kappa \mathrm{B}$, nuclear factor- $\kappa \mathrm{B}$; mTOR, mammalian target of rapamycin; S6K1, S6 kinase 1; NLS, nuclear localization signal; TNF- $\alpha$, tumor necrosis factor- $\alpha$; TSC, tuberous sclerosis complex; Raptor, regulatory associated protein of mTOR; Rheb, ras homolog enriched brain; PA, phosphatidic acid; siRNA, short interfering RNA Received 17.1.12; revised 25.6.12; accepted 2.8.12; Edited by C Duckett; published online 07.9.12
} 
S6K1 to the nucleus. p70 S6K1, which lacks the sequence, is mainly cytoplasmic. ${ }^{16,17}$ Phosphorylation at position T389 of p70 or the equivalent site in p85 (T412) is required for a full and sustained activation of S6K1. Consequently, the extent of S6K1 (T389/412) phosphorylation in cells is routinely used as a surrogate for mTORC1 signaling activity. ${ }^{18,19}$ It has been shown that $\mathrm{p} 70$ and p85 S6K1 are concordantly activated by growth factors and nutrients in a rapamycin-sensitive manner; ${ }^{18}$ however, most of the previous studies focus on p70 S6K1, and little is known about p85 S6K1 regulation and function.

In the present study, through investigating the roles of IKK and mTORC1-S6K1 in the cell death induced by chronic $\mathrm{H}_{2} \mathrm{O}_{2}$ insult, we have identified IKK- $\beta$ as a mediator of cell death independent of the canonical NF- $\kappa$ B pathway during oxidative stress and uncovered a novel signaling mechanism that is responsible for $\mathrm{H}_{2} \mathrm{O}_{2}$-induced phosphorylation of $\mathrm{Mdm} 2$ (S166), p53 stabilization and cell death. The unexpected function of IKK- $\beta$-p85 S6K1 not only presents a mechanism for aberrant cell death induced by chronic insult with high levels of ROS under pathological conditions, but also links two of the major pathways that control cell growth/proliferation and cell death/survival.

\section{Results}

IKK- $\beta$ contributes to hydrogen peroxide-induced cell death via a NF- $\kappa$ B-independent pathway. To determine the function of IKK in ROS-induced cell death, we examined the effects of IKK inhibition and overexpression on cell death, following $\mathrm{H}_{2} \mathrm{O}_{2}$ exposure. We found that $\mathrm{H}_{2} \mathrm{O}_{2}$ treatment caused breast cancer MCF-7 cell death in a dose- and timedependent manner (Figures $1 \mathrm{a}$ and $\mathrm{b}$ ). $\mathrm{H}_{2} \mathrm{O}_{2}$ at a concentration of $1 \mathrm{mM}$ was used in the subsequent experiments, which induced significant $(51.9 \%)$ cell death within $36 \mathrm{~h}$ (Figure 1a). Interestingly, knockdown of IKK- $\beta$, but not IKK- $\alpha$ remarkably prevented MCF-7 cells from $\mathrm{H}_{2} \mathrm{O}_{2}$-induced cell death (Figures 1c and d). Moreover, pretreatment of MCF-7 cells with IKK-specific inhibitors, Bay 11-7082 or wedelolactone, significantly $(P<0.05)$ attenuated $\mathrm{H}_{2} \mathrm{O}_{2}$-induced MCF-7 cell death (Figure 1e). To further confirm the pro-death role of IKK- $\beta$, we expressed HA-IKK- $\alpha$ or HA-IKK- $\beta$ in MCF-7 cells and found that IKK- $\beta$, but not IKK- $\alpha$, overexpression sensitized MCF-7 cells to $\mathrm{H}_{2} \mathrm{O}_{2}$-induced cell death (Figure 1f). The preventive effect of IKK- $\beta$ knockdown for $\mathrm{H}_{2} \mathrm{O}_{2}$-induced cell death was also observed in other cell lines such as HeLa and HCT-116 cells (Supplementary Figure 1). These results suggest that IKK- $\beta$ is critical for $\mathrm{H}_{2} \mathrm{O}_{2}$-induced cell death.

As $\mathrm{NF}-\kappa \mathrm{B}$ functions downstream of IKK- $\beta$, we then tested whether NF- $\kappa$ B mediated the effect of IKK- $\beta$ on $\mathrm{H}_{2} \mathrm{O}_{2}$-induced cell death. Surprisingly, proteasome inhibitor MG132, which inhibits NF- $\kappa \mathrm{B}$ translocation and activation by preventing the degradation of $\mathrm{I}_{\kappa} \mathrm{B}-\alpha,{ }^{20}$ did not decrease $\mathrm{H}_{2} \mathrm{O}_{2}$-induced cell death (Figure 1g). Moreover, p65 siRNA, was also unable to impair $\mathrm{H}_{2} \mathrm{O}_{2}$-induced MCF-7 cell death (Figure 1h). Downregulation of IKK- $\alpha / \beta$ or p65 by siRNA and inhibitors ( 1 or $3 \mu \mathrm{M}$ of Bay $11-7082,5$ or $10 \mu \mathrm{M}$ of wedelolactone and 250 or $500 \mathrm{nM}$ of MG132) did not induce significant cell death in the absence of $\mathrm{H}_{2} \mathrm{O}_{2}$ (Figure 1c and Supplementary Figure 2).
These observations suggest that classical NF- $\kappa$ B pathway is not required for IKK- $\beta$-mediated cell death during oxidative stress.

Taken together, these findings indicate that IKK- $\beta$ mediates $\mathrm{H}_{2} \mathrm{O}_{2}$-induced cell death independent of the canonical NF- $\kappa \mathrm{B}$ pathway.

p85 S6K1 potentiates hydrogen peroxide-induced cell death via a rapamycin-insensitive mechanism. The mechanisms through which IKK- $\beta$ mediates $\mathrm{H}_{2} \mathrm{O}_{2}$-induced cell death were further investigated. Recent reports show that multiple proteins distinct from $\mid \kappa B$ proteins are phosphorylated by IKK- $\alpha$ or IKK- $\beta .^{21} \mathrm{IKK}-\beta$ has been found to mediate tumor necrosis factor- $\alpha$ (TNF- $\alpha$ )-stimulated mTORC1-S6K1 signaling activity by phosphorylating tuberous sclerosis complex 1.22 Although the pro-survival role of mTORC1-S6K1 has been well established, ${ }^{23,24}$ a few recent studies reported a pro-cell death function of mTORC1-S6K1 in response to endoplasmic reticulum stress or genotoxic agents (doxorubicin)-induced DNA damage in MEFs. ${ }^{25-27}$

To investigate the possible role of mTORC1-S6K1 in IKKmediated cell death under oxidative stress, the effect of mTORC1 inhibition on $\mathrm{H}_{2} \mathrm{O}_{2}$-induced cell death was examined in MCF-7 cells. Unexpectedly, rapamycin treatment failed to prevent the cell death induced by either $\mathrm{H}_{2} \mathrm{O}_{2}$ or HA-IKK- $\beta$ overexpression (Figure 2a). Similarly, mTORC1 downregulation by mTOR or Raptor siRNA (Figure 2b) was also unable to inhibit the $\mathrm{H}_{2} \mathrm{O}_{2}$-induced cell death, suggesting that $\mathrm{mTORC} 1$ is not required for IKK- $\beta$-mediated cell death under oxidative stress. Moreover, depletion of ras homologenriched brain (Rheb), a key upstream activator of mTORC1, strongly decreased P-S6 (S235/236) levels, but exerted no significant effect on $\mathrm{H}_{2} \mathrm{O}_{2}$-induced cell death (Figure $2 \mathrm{c}$ ). In contrast, S6K1 siRNA dramatically repressed $\mathrm{H}_{2} \mathrm{O}_{2}$-induced cell death (Figures $2 \mathrm{~d}$ and e). The protective effect of S6K1 knockdown on $\mathrm{H}_{2} \mathrm{O}_{2}$-induced cell death was also observed in HeLa and HCT-116 cells (Supplementary Figure 3). As S6K1 siRNA could reduce the levels of both p70 S6K1 and p85 S6K1, we surmised that p85, but not p70 S6K1, might have a role in the $\mathrm{H}_{2} \mathrm{O}_{2}$-induced cell death. Accordingly, we examined the effects of p70 S6K1 or p85 S6K1 overexpression on $\mathrm{H}_{2} \mathrm{O}_{2}$ induced cell death. Overexpression of p85, but not of p70 S6K1, drastically enhanced $\mathrm{H}_{2} \mathrm{O}_{2}$-induced cell death (Figure 2f). This observation demonstrates a distinct function of p85 S6K1 in oxidative stress-induced cell death, and suggests that p85, but not p70 S6K1, promotes cell death via a rapamycin-insensitive and mTORC1-independent mechanism under oxidative stress.

Hydrogen peroxide activates p85 S6K1 through a rapamycin-insensitive mechanism. Different roles of p70 and p85 $56 \mathrm{~K} 1$ in $\mathrm{H}_{2} \mathrm{O}_{2}$-induced cell death indicates that these two isoforms may be differentially regulated. We hence examined the activation of p70 and p85 S6K1 in response to various signals that are known to simulate mTORC1 activity. Consistent with the previous findings, nutrients (amino acids) or insulin strongly stimulated the phosphorylation of T389 on p70 and T412 on p85 S6K1 in MCF-7 cells starved for amino acids or serum. The insulin and nutrient-stimulated phosphorylation was completely blocked by pre-treating the cells 

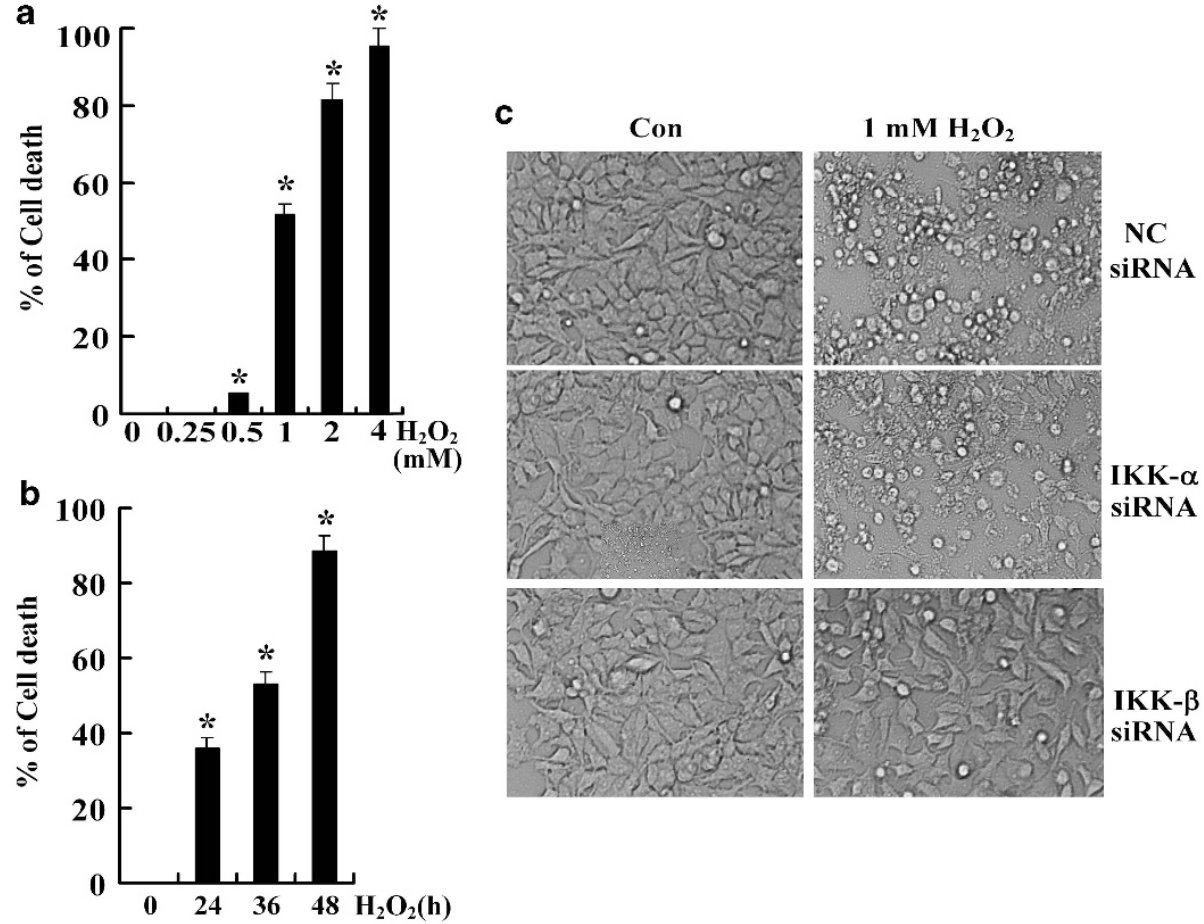

SiRNA
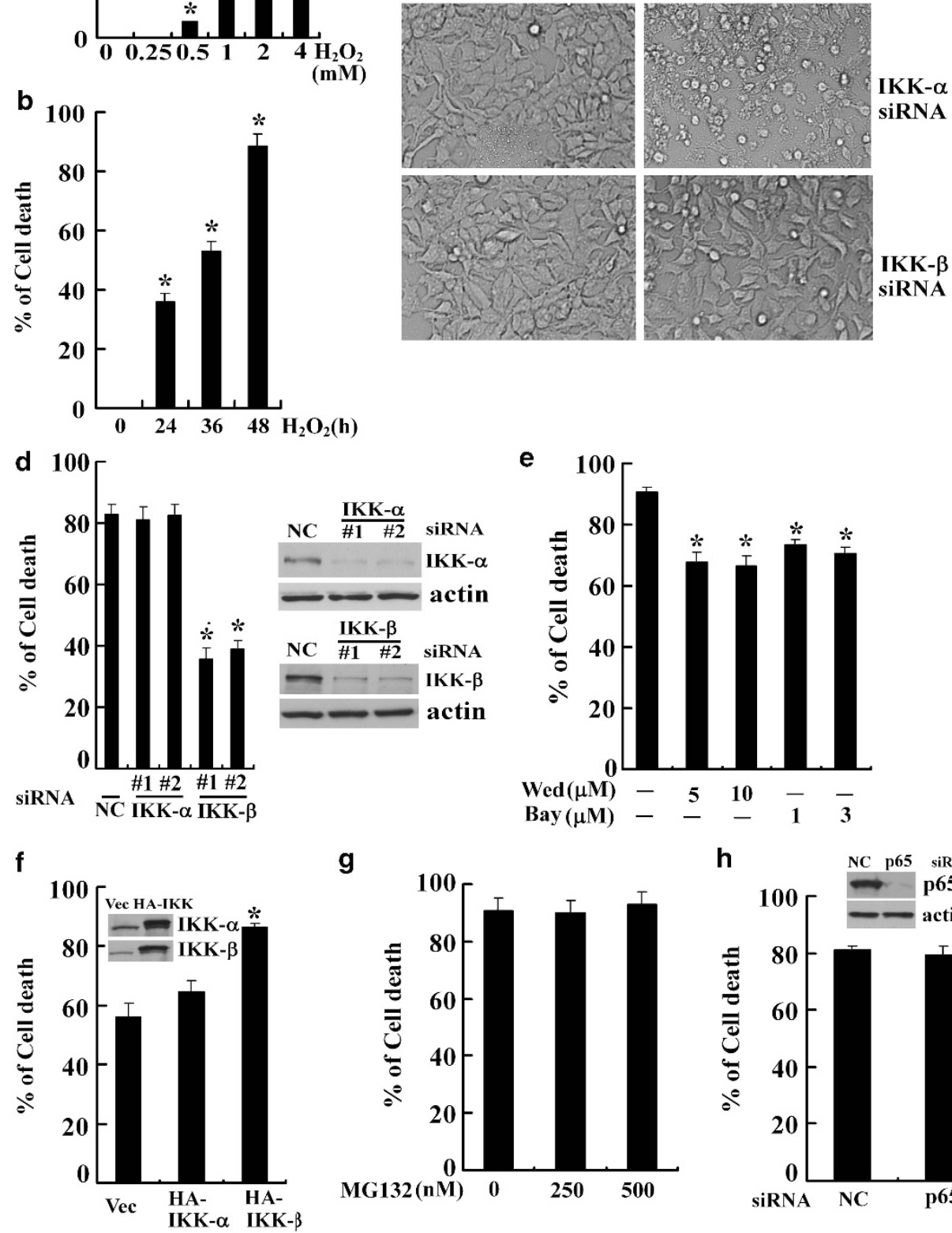

g
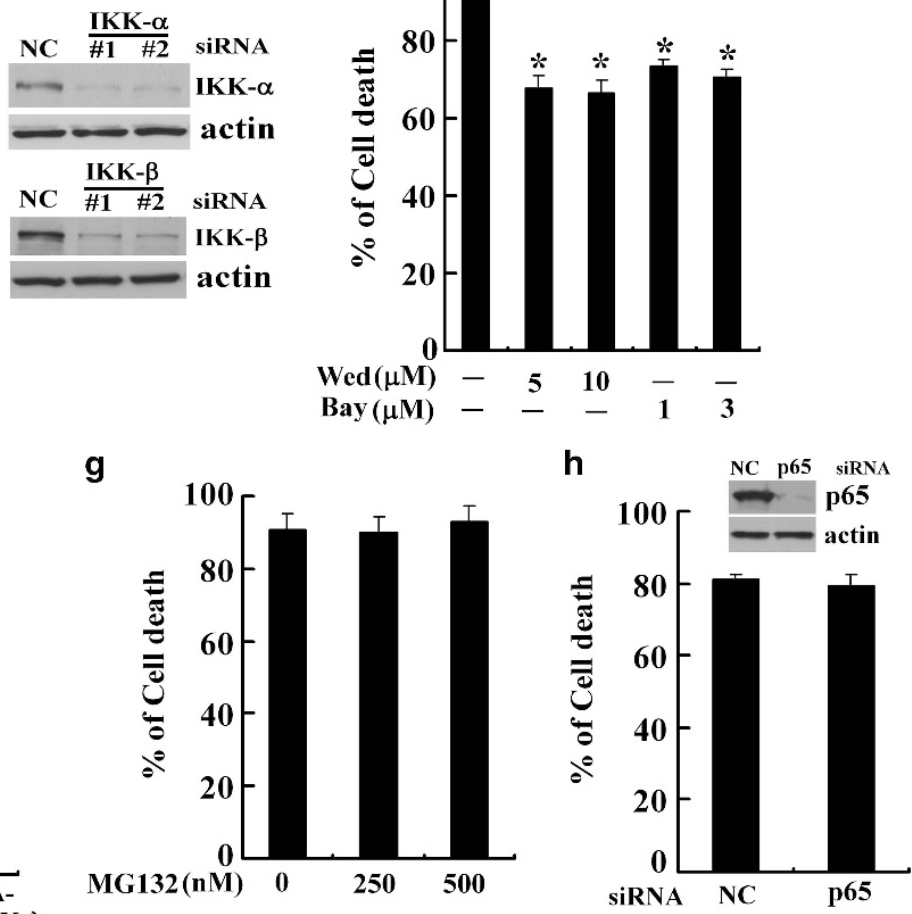

Figure 1 IKK- $\beta$ mediates $\mathrm{H}_{2} \mathrm{O}_{2}$-induced cell death via NF- $\kappa$ B-independent pathway. (a) MCF-7 cells were incubated with indicated doses of $\mathrm{H}_{2} \mathrm{O}_{2}$ for $36 \mathrm{~h}$ or $(\mathbf{b}) 1 \mathrm{mM}$ of $\mathrm{H}_{2} \mathrm{O}_{2}$ for indicated times and the viability of the cells was analyzed by cell viability assay. ${ }^{*} P<0.05$ compared with control. (c and d) IKK- $\beta$ knockdown suppressed $\mathrm{H}_{2} \mathrm{O}_{2}$ induced cell death. MCF-7 cells were transfected with negative control (NC), IKK- $\beta$ or IKK- $\alpha$ siRNA for $48 \mathrm{~h}$ and incubated with $1 \mathrm{mM} \mathrm{H} \mathrm{H}_{2} \mathrm{O}_{2}$ for another $48 \mathrm{~h}$. Cell viability was analyzed by cell viability assay and the levels of IKK- $\beta$ or IKK- $\alpha$ were determined by immunoblotting. ${ }^{*} P<0.05$ compared with NC. (e) IKK inhibitors reduced $\mathrm{H}_{2} \mathrm{O}_{2}$-stimulated cell death. After pretreatment with indicated doses of Bay 11-7082 (Bay) or wedelolactone (Wed) for $30 \mathrm{~min}, \mathrm{MCF}-7$ cells were subsequently incubated with $1 \mathrm{mM} \mathrm{H} \mathrm{H}_{2} \mathrm{O}_{2}$ for $48 \mathrm{~h}$ and subjected to cell viability assay. ${ }^{*} P<0.05$ compared with control. (f) IKK- $\beta$ overexpression sensitizes cells to $\mathrm{H}_{2} \mathrm{O}_{2}$-induced death. MCF-7 cells were transfected with HA-IKK- $\beta$ or HA-IKK- $\alpha$ or empty vector for $24 \mathrm{~h}$ and subsequently incubated with $1 \mathrm{mM} \mathrm{H}_{2} \mathrm{O}_{2}$ for another $36 \mathrm{~h}$. Cells were analyzed for cell viability and expression levels of IKK- $\beta$ or IKK- $\alpha$. ${ }^{*} P<0.05$ compared with control and IKK- $\alpha$. (g) MCF-7 cells were pretreated with 250 or $500 \mathrm{nM}$ of MG132, or (h) transfected with NC or p65 siRNA for $48 \mathrm{~h}$, followed by incubation with $1 \mathrm{mM}$ of $\mathrm{H}_{2} \mathrm{O}_{2}$ for another $48 \mathrm{~h}$. Cells were then analyzed for cell viability assay and p65 protein levels 

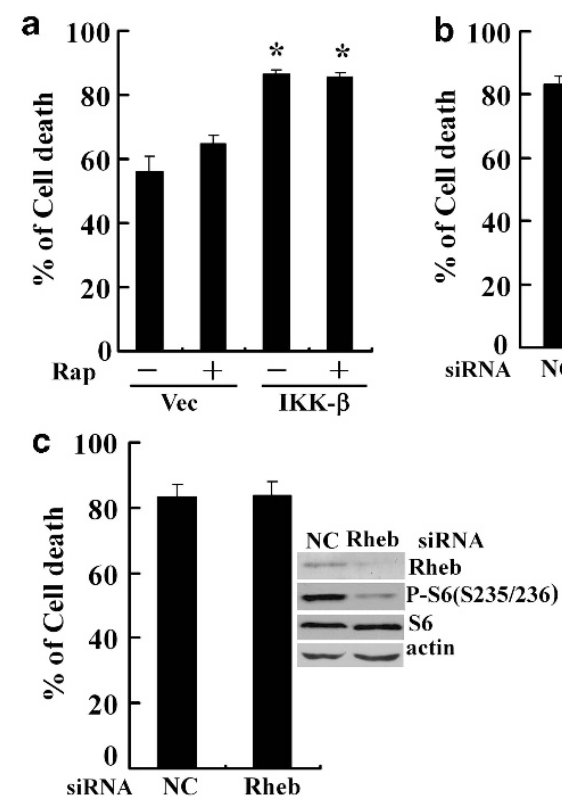
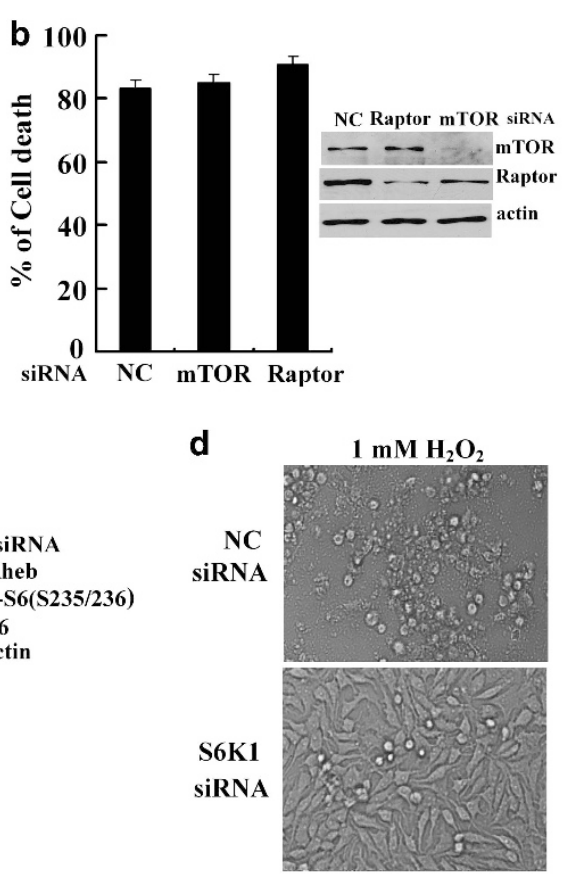
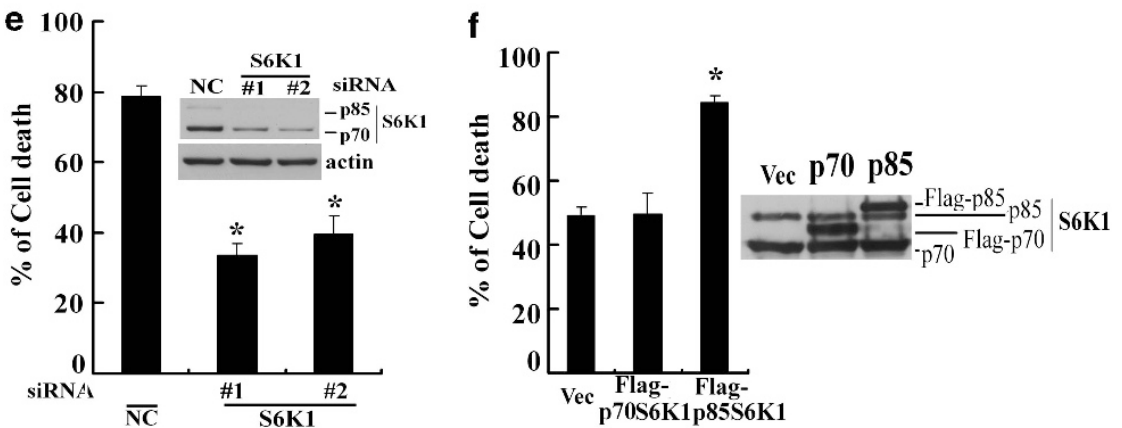

Figure 2 p85, but not p70 S6K1, promotes $\mathrm{H}_{2} \mathrm{O}_{2}$-induced cell death via a rapamycin-insensitive mechanism. (a) Rapamycin does not prevent IKK- $\beta$-mediated cell death. MCF-7 cells were transfected with HA-IKK- $\beta$ for $24 \mathrm{~h}$ and incubated with $1 \mathrm{mM}$ of $\mathrm{H}_{2} \mathrm{O}_{2}$ and $100 \mathrm{nM}$ of rapamycin (Rap) for another $36 \mathrm{~h}$. The cells were then assayed for cell viability. ${ }^{*} P<0.05$ compared with vector control. (b and $\mathbf{c}$ ) mTORC1 downregulation does not affect $\mathrm{H}_{2} \mathrm{O}_{2}$-induced cell death. MCF-7 cells were transfected with (b) control (NC), mTOR, Raptor siRNA or (c) Rheb siRNA for $48 \mathrm{~h}$ followed by incubation with $1 \mathrm{mM}$ of $\mathrm{H}_{2} \mathrm{O}_{2}$ for another $48 \mathrm{~h}$. The cells were assayed for cell viability and expression levels of mTOR, Raptor, Rheb and phospho-S6 (S235/236). (d and e) S6K1 knockdown suppresses $\mathrm{H}_{2} \mathrm{O}_{2}$-induced cell death. MCF-7 cells were transfected with S6K1 siRNA for $48 \mathrm{~h}$ followed by incubation with $1 \mathrm{mM}$ of $\mathrm{H}_{2} \mathrm{O}_{2}$ for another $48 \mathrm{~h}$. The cells were assayed for viability and $\mathrm{S} 6 \mathrm{~K} 1$ protein levels. ${ }^{*} P<0.05 \mathrm{compared}$ with $\mathrm{NC}$. (f) p85 S6K1 overexpression enhances $\mathrm{H}_{2} \mathrm{O}_{2}$-induced cell death. MCF-7 cells were transfected with flag-p70 or flag-p85 S6K1 vector for $24 \mathrm{~h}$ and then incubated with $1 \mathrm{mM} \mathrm{H} \mathrm{H}_{2} \mathrm{O}_{2}$ for another $36 \mathrm{~h}$. The cells were assayed for viability and p70/85 S6K1 levels. ${ }^{*} P<0.05$ compared with control and p70 S6K1

with rapamycin (Figure 3a). Treating the cells with inflammatory factor TNF- $\alpha$ also induced the phosphorylation. However, while the TNF- $\alpha$-stimulated phosphorylation at T389 of p70 was inhibited by rapamycin, the phosphorylation on T412 of p85 was insensitive to the drug (Figure $3 b$ ). Similarly, $\mathrm{H}_{2} \mathrm{O}_{2}$ stimulated the phosphorylation on T412 of p85, but not T389 of p70 S6K1. The $\mathrm{H}_{2} \mathrm{O}_{2}$-induced phosphorylation was also insensitive to rapamycin and Pp242, which is an ATP site-specific inhibitor of mTOR that inhibits both mTORC1 and mTORC2 (Figures $3 \mathrm{~b}$ and c). These findings suggest that activation of p85 S6K1 by $\mathrm{H}_{2} \mathrm{O}_{2}$ is independent of mTOR kinase. As mitogen-stimulated mTORC1 and S6K1 activation requires the presence of nutrient, we further examined whether $\mathrm{H}_{2} \mathrm{O}_{2}$ was able to stimulate phosphorylation of p85 at T412 in cells starved for amino acids or treated with rapamycin. As shown in
Figure $3 d$ and Supplementary Figure $4, \mathrm{H}_{2} \mathrm{O}_{2}$ increased phosphorylation of p85 (T412), but not that of p70 S6K1 (T389) in amino acids-starved or rapamycin-treated MCF-7, HeLa and HCT116 cells (Figure $3 d$ and Supplementary Figure 4). 4E-BP1, another downstream target of mTORC1, had similar response to that of p70 S6K1 (Supplementary Figure 5).

S6 is the first identified and the most important p70/p85 S6K1 substrate. It has been well established that phosphorylation of S6 on S235/236 correlates with its function in protein synthesis and cell-size control. ${ }^{28}$ We further determined whether $\mathrm{H}_{2} \mathrm{O}_{2}$ was able to stimulate phosphorylation of $\mathrm{S} 6$ (S235/236) in the presence of rapamycin. We found that $\mathrm{H}_{2} \mathrm{O}_{2}$ dose- and time-dependently increased the phosphorylation in rapamycin-treated MCF-7 and $\mathrm{HCT}-116$ cells (Figures $3 \mathrm{~b}$ and $\mathrm{c}$ and Supplementary Figure 6). An in vitro S6K kinase assay 


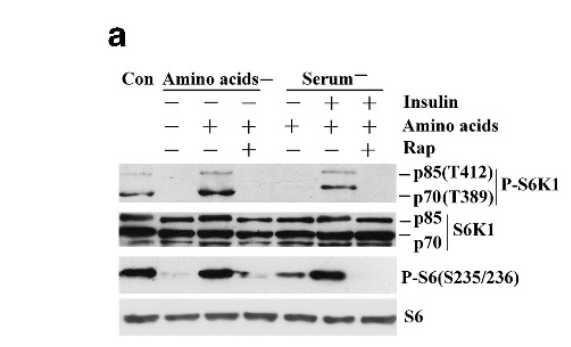

b
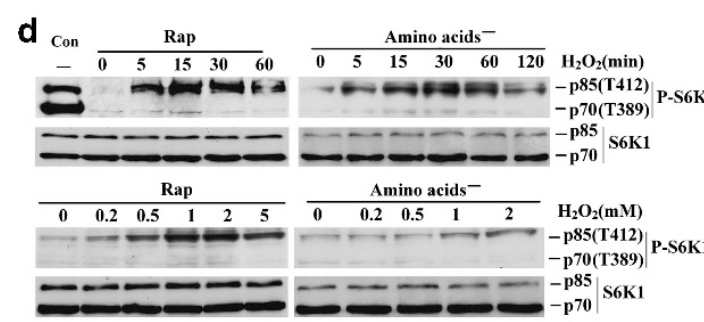

Amino acids -

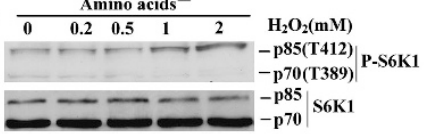

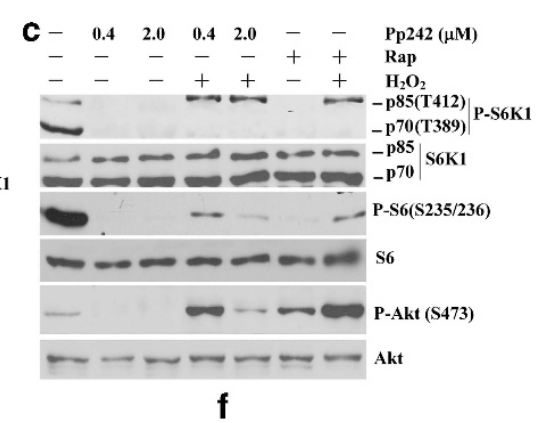

e

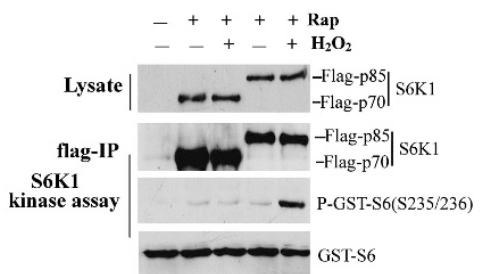

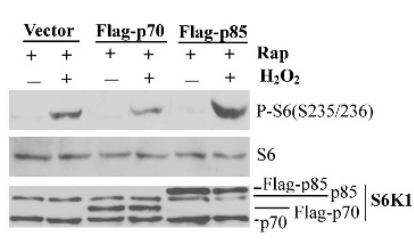

Figure $3 \quad \mathrm{H}_{2} \mathrm{O}_{2}$ activates p85, but not p70 S6K1 in a rapamycin-insensitive way. (a) Insulin and amino acid-stimulated activation of p70 and p85 S6K1 is sensitive to rapamycin. MCF-7 cells were incubated in DPBS for $1 \mathrm{~h}$ or in serum-free DMEM for $24 \mathrm{~h}$. Cells were then stimulated with $1 \times$ amino acids for $30 \mathrm{~min}$ or $100 \mathrm{ng} / \mathrm{ml}$ insulin for $15 \mathrm{~min}$ in the presence or absence of $100 \mathrm{nM}$ rapamycin. (b) $\mathrm{H}_{2} \mathrm{O}_{2}$ - and TNF- $\alpha$-induced activation of p85 S6K1 is insensitive to rapamycin. After pretreatment with $100 \mathrm{nM}$ of rapamycin or drug vehicle for $30 \mathrm{~min}$, MCF-7 cells were stimulated with $1 \mathrm{mM}$ of $\mathrm{H}_{2} \mathrm{O}_{2}$ or $20 \mathrm{ng} / \mathrm{ml}$ of TNF- $\alpha$ for $30 \mathrm{~min}$. The cells were assayed by immunoblotting for levels of phosphor-p70/85 (T389/412) S6K1, p70/85 S6K1, phospho-S6 (S235/236) and S6. (c) $\mathrm{H}_{2} \mathrm{O}_{2}$-stimulated p85 S6K1 activation does not require mTOR kinase activity. MCF-7 cells were pretreated with $100 \mathrm{nM}$ of rapamycin or 0.4 or $2 \mu \mathrm{M} \mathrm{Pp} 242$ for $1 \mathrm{~h}$ followed by incubation with $1 \mathrm{mM}$ of $\mathrm{H}_{2} \mathrm{O}_{2}$ for 30 min. The cells were assayed by immunoblotting for levels of phospho-p70/85 (T389/412) S6K1 and p70/85 S6K1, phospho-S6 (S235/236), S6, phospho-Akt (S473) or Akt antibody. (d) Rapamycin-insensitive and amino acids-independent activation of p85. MCF-7 cells were pretreated with $100 \mathrm{nM}$ rapamycin for $1 \mathrm{~h}$, or incubated in DPBS for $1 \mathrm{~h}$, followed by stimulation with indicated doses of $\mathrm{H}_{2} \mathrm{O}_{2}$ for 30 min or $1 \mathrm{mM}$ of $\mathrm{H}_{2} \mathrm{O}_{2}$ for indicated times. Lysates from the cells were subjected to immunoblotting analysis for levels of phospho-p70/85 (T389/412) S6K1, p70/85 S6K1. (e) p85 S6K1 activates S6 independent of mTORC1. MCF-7 cells transfected with flag-p70 S6K1 or flag-p85 S6K1 were stimulated with $1 \mathrm{mM}$ of $\mathrm{H}_{2} \mathrm{O}_{2}$ for $30 \mathrm{~min}$ in the presence of $100 \mathrm{nM}$ rapamycin. Cells were then lysed and immunoprecipitated with anti-flag antibody. The precipitated flag-S6Ks were assayed for kinase activity against recombinant S6 in vitro. (f) MCF-7 cells transfected with flag-p70 S6K1 or flag-p85 S6K1 were stimulated with $1 \mathrm{mM}$ of $\mathrm{H}_{2} \mathrm{O}_{2}$ for 30 min in the presence of $100 \mathrm{nM}$ rapamycin. Lysates from the cells were analyzed by immunoblotting for levels of phospho-S6 (S235/236), S6, phospho-p70/85 (T389/412) S6K1and p70/85 S6K1. Con, control; Rap, rapamycin

revealed that ectopically expressed p85, but not p70, S6K1 purified from rapamycin-pretreated and $\mathrm{H}_{2} \mathrm{O}_{2}$-stimulated MCF-7 cells phosphorylated GST-S6 (S235/236) in vitro (Figure 3e). Consistent with this result, overexpressing p85, but not p70 S6K1, enhanced the $\mathrm{H}_{2} \mathrm{O}_{2}$-stimulated phosphorylation of $\mathrm{S} 6$ (S235/236) in cells (Figure 3f). Taken together, these results suggest that $\mathrm{H}_{2} \mathrm{O}_{2}$ activates p85, but not p70 S6K1, through an mTOR kinase-independent mechanism.

IKK- $\beta$ is required for the rapamycin-insensitive activation of p85 S6K1 under oxidative stress. We further investigated the mechanisms of $\mathrm{H}_{2} \mathrm{O}_{2}$-induced rapamycininsensitive activation of p85 $\mathrm{S} 6 \mathrm{~K} 1$. IKK is a major downstream kinase in the $\mathrm{H}_{2} \mathrm{O}_{2}$ and TNF- $\alpha$ signaling pathway, ${ }^{6}$ and has been shown to regulate mTORC1-S6K1. ${ }^{22,29-31}$ Indeed, $\mathrm{H}_{2} \mathrm{O}_{2}$ stimulated the phosphorylation of IKK- $\alpha / \beta \quad(\mathrm{S} 176 / 180)$ and degradation of $\mathrm{I}_{\kappa} \mathrm{B}-\alpha$ in MCF-7 cells (Figure $4 \mathrm{a}$ ). To determine the role of $\mathrm{IKK}$ in $\mathrm{H}_{2} \mathrm{O}_{2}$-stimulated p85 S6K1 activation, we used chemical inhibitors or siRNA to block IKK activity. We found that IKK-specific inhibitor wedelolactone, but not $\mathrm{PI}-3 \mathrm{~K}$ inhibitor Ly294002, decreased $\mathrm{H}_{2} \mathrm{O}_{2}$-stimulated p85 S6K1 (T412) and S6 (S235/236) phosphorylation in the presence of rapamycin (Figure $4 \mathrm{~b}$ and Supplementary Figure 7). Furthermore, downregulation of IKK- $\beta$, but not IKK- $\alpha$, prevented $\mathrm{H}_{2} \mathrm{O}_{2}$ stimulated phosphorylation of p85 S6K1 (T412) (Figure 4c). These results suggest that IKK- $\beta$ is required for the rapamycininsensitive activation of $\mathrm{p} 85 \mathrm{~S} 6 \mathrm{~K} 1$.
Association of IKK- $\beta$ with p85 S6K1 is required for $\mathrm{H}_{2} \mathrm{O}_{2^{-}}$ induced p86 S6K1 activation. The requirement of IKK- $\beta$ in $\mathrm{H}_{2} \mathrm{O}_{2}$-induced p85 S6K1 activation raised a possibility that IKK- $\beta$ may interact with and phosphorylate p85 S6K1 directly. Indeed, we found that ectopically expressed IKK- $\beta$ was able to co-immunoprecipitate with p85, but not p70, S6K1 (Figure 5a). Furthermore, the association between IKK- $\beta$ and p85-S6K1 was enhanced upon $\mathrm{H}_{2} \mathrm{O}_{2}$ stimulation (Figure 5a). The association was further validated by Co-IP of endogenous IKK- $\beta$ with p85 S6K1 (Figure 5b). In addition, immunofluoresence staining confirmed that these two proteins co-localized in the cytoplasm of the cells (Supplementary Figure 8). The cytoplasmic and nuclear localization of both p85 and p70 S6K1 was further confirmed by fluorescence analysis of exogenously expressed pEGFPor flag-tagged p70 and p85 S6K1 and nuclear-cytoplasmic fractionation analysis of endogenous p70 and p85 S6K1 (Supplementary Figure 9).

We next performed IKK- $\beta$ in vitro kinase assay to examine whether IKK- $\beta$ was able to phosphorylate p85 S6K1 directly. Our result showed that although IKK- $\beta$ purified from $\mathrm{H}_{2} \mathrm{O}_{2}-$ treated MCF-7 cells phosphorylated GST-I $\mathrm{B}-\alpha(\mathrm{S} 32 / 36)$, it was ineffective for phosphorylation of bacterial-expressed and purified his-p85 S6K1 (T412) or his-p70 S6K1 (T389) in vitro (Figure $5 \mathrm{c}$ ). This finding indicates that alternative kinase other than IKK- $\beta$ may direct the $\mathrm{H}_{2} \mathrm{O}_{2}$-induced phsophorylation of p85 S6K1. 


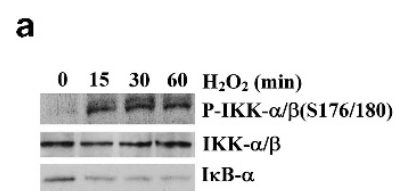

b

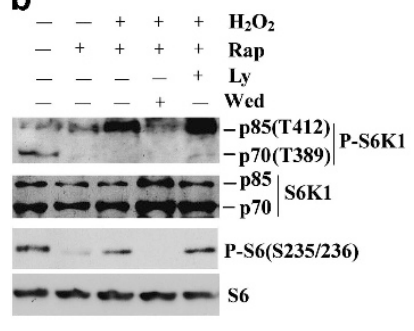

c
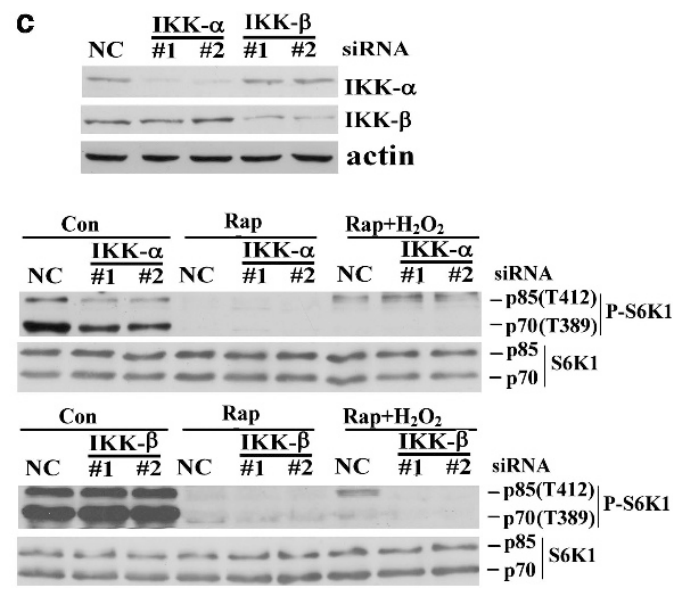

Figure 4 IKK- $\beta$ is required for mTORC1-independent activation of p85 S6K1. (a) $\mathrm{H}_{2} \mathrm{O}_{2}$ activates IKK. MCF-7 cells were stimulated with $1 \mathrm{mM}$ of $\mathrm{H}_{2} \mathrm{O}_{2}$ for various times and the levels of phospho-IKK- $\alpha / \beta$ (S176/180) and $\mathrm{I}_{\kappa} \mathrm{B}-\alpha$ were analyzed by immunoblotting. (b) MCF-7 cells pretreated with $100 \mathrm{nM}$ of rapamycin (Rap) and $20 \mu \mathrm{M}$ of Ly294002 (LY) or $50 \mu \mathrm{M}$ of wedelolactone (Wed) for $1 \mathrm{~h}$ were stimulated with $1 \mathrm{mM}$ of $\mathrm{H}_{2} \mathrm{O}_{2}$ for $30 \mathrm{~min}$. (c) MCF-7 cells were transfected with IKK- $\alpha$ or IKK- $\beta$ or control siRNA and stimulated with $1 \mathrm{mM}$ of $\mathrm{H}_{2} \mathrm{O}_{2}$ for $30 \mathrm{~min}$ in the presence of $100 \mathrm{nM}$ of rapamycin. Lysates from the cells were analyzed by immunoblotting for the levels of IKK- $\alpha$, IKK- $\beta$, $\beta$-actin, phospho-p70/85 (T389/412) S6K1, p70/85 S6K1, phospho-S6 (S235/236) and S6

A recent study has shown that IKK- $\beta$ acts as an adaptor protein for $I_{\kappa} \mathrm{B}-\alpha$ degradation independently of its kinase activity in UV-induced NF- $\kappa \mathrm{B}$ activation. ${ }^{32}$ IKK- $\beta$ brings $\beta$-TrCP to $\mathrm{I}_{\kappa} \mathrm{B}-\alpha$ through interaction with $\beta$-TrCP via its $\mathrm{N}$-terminal kinase domain and with $\mathrm{I}_{\kappa} \mathrm{B}-\alpha$ via $\mathrm{C}$-terminal regulatory region, leading to $\mathrm{I}_{\kappa} \mathrm{B}-\alpha$ ubiquitinaiton and degradation. ${ }^{32}$ However, we found that neither the kinase-dead IKK- $\beta$ mutant (IKK- $\beta$ KD) nor the $\mathrm{C}$-terminal regulatory region (291-756 aa) and the N-terminal kinase domain (1-308 aa) of IKK- $\beta$ were able to associate with p85 S6K1 and stimulate p85 S6K1 phosphorylation upon $\mathrm{H}_{2} \mathrm{O}_{2}$ exposure (Figures $5 \mathrm{~d}$ and e). Furthermore, knockdown of IKK- $\gamma$, a regulatory component of IKK complex essential for IKK- $\beta$ kinase activity and activation of the classical IKK/NF- $\kappa$ B pathway, also repressed p85 S6K1 phosphorylation and MCF-7 cell death following $\mathrm{H}_{2} \mathrm{O}_{2}$ exposure (Supplementary Figure 10). These findings suggest that both the kinase activity of IKK- $\beta$ and the association of p85 S6K1 with IKK- $\beta$ are required for the activation of $p 85 \mathrm{~S} 6 \mathrm{~K} 1$ by $\mathrm{H}_{2} \mathrm{O}_{2}$.

IKK- $\beta$ mediates hydrogen peroxide-induced cell death via activation of p85 S6K1-Mdm2-p53 pathway. Mdm2 is an E3 ligase, which mainly ubiquitinates p53 in the nucleus and promotes p53 nuclear export and degradation. ${ }^{33}$ It has been shown recently that $\mathrm{mTORC1-S6K1}$ mediated MEF cell death in response to doxorubicin-induced DNA damage by phosphorylation of Mdm2 at S163 (mouse), and inhibited its nuclear entry, which prevented Mdm2-mediated p53 ubiquitination and inducing p53 accumulation. ${ }^{25}$ Interestingly, $\mathrm{H}_{2} \mathrm{O}_{2}$ also dose-dependently stimulated phosphorylation of Mdm2 on S166 (human) in MCF-7 cells, an equivalent site to S163 in mouse (Figure 6a). Even though the basal level of phosphorylated Mdm2 (S166) was slightly decreased by rapamycin treatment, the $\mathrm{H}_{2} \mathrm{O}_{2}$-induced phosphorylation was rapamycin-insensitive (Figure 6a). Moreover, knockdown of IKK- $\beta$ or S6K1 by siRNA suppressed the phosphorylation (Figure 6b), suggesting critical roles of IKK- $\beta$ and S6K1 in the $\mathrm{H}_{2} \mathrm{O}_{2}$-stimulated Mdm2 (S166) phosphorylation. This notion was further confirmed by the observation that overexpression of IKK- $\beta$ and p85 S6K1, but not p70 S6K1, significantly increased the levels of phosphorylated Mdm2 (S166) (Figure 6c). These findings demonstrate a requirement of IKK- $\beta$ and p85 S6K1 in $\mathrm{H}_{2} \mathrm{O}_{2}$-induced, rapamycin-insensitive phosphorylation of Mdm2 (S166).

We further examined the effect of $\mathrm{H}_{2} \mathrm{O}_{2}$ on p53 induction and possible roles of IKK- $\beta$ and p85 S6K1 in regulation of p53. $\mathrm{H}_{2} \mathrm{O}_{2}$ treatment caused a time-dependent increase of p53 protein level (Figure 7a). The induction of p53 by $\mathrm{H}_{2} \mathrm{O}_{2}$ was suppressed in cells pre-treated with IKK-specific inhibitor wedelolactone, but not in those treated with rapamycin (Figure 7a). Consistently, IKK- $\beta$ or S6K1 knockdown impaired the $\mathrm{H}_{2} \mathrm{O}_{2}$-induced p53 accumulation (Figure 7b). These observations suggest that IKK- $\beta$ and p85 S6K1 are required for the $\mathrm{H}_{2} \mathrm{O}_{2}$-stimulated p53 induction.

To determine whether activation of $\mathrm{p} 85 \mathrm{~S} 6 \mathrm{~K} 1$ and induction of $\mathrm{p} 53$ is required for $\mathrm{IKK}-\beta$-mediated cell death, we next examined the effect of p85 S6K1 knockdown or overexpression on IKK- $\beta$-mediated cell death. As expected, downregulation of S6K1 prevented the cell death induced by IKK$\beta$ overexpression (Figure 7c), whereas overexpression of p85 S6K1, but not p70 S6K1, reversed the protective effect of the IKK- $\beta$ knockdown (Figure 7d). Most importantly, p53 siRNA inhibited cell death induced by $\mathrm{H}_{2} \mathrm{O}_{2}$, but repressed the protective effects of IKK- $\beta$ or S6K1 knockdown (Figure 7e), suggesting an important role for p53 in IKK- $\beta$ - and S6K1mediated cell death under oxidative stress.

Collectively, these results support a model that IKK- $\beta$ mediates $\mathrm{H}_{2} \mathrm{O}_{2}$-induced cell death via activation of p85 S6K1Mdm2-p53 signaling pathway.

\section{Discussion}

Activation of IKK- $\beta$ has been generally viewed as a major contributor to cell survival and proliferation. However, in the present study, we show that IKK- $\beta$ also possesses a prodeath function that is independent of its role in regulation of $\mathrm{NF}-\kappa \mathrm{B}$. Our findings suggest that the pro-death function of IKK 


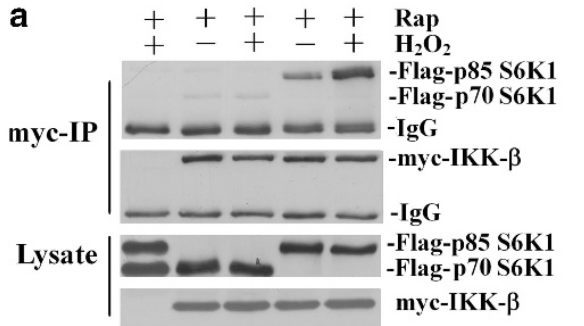

b
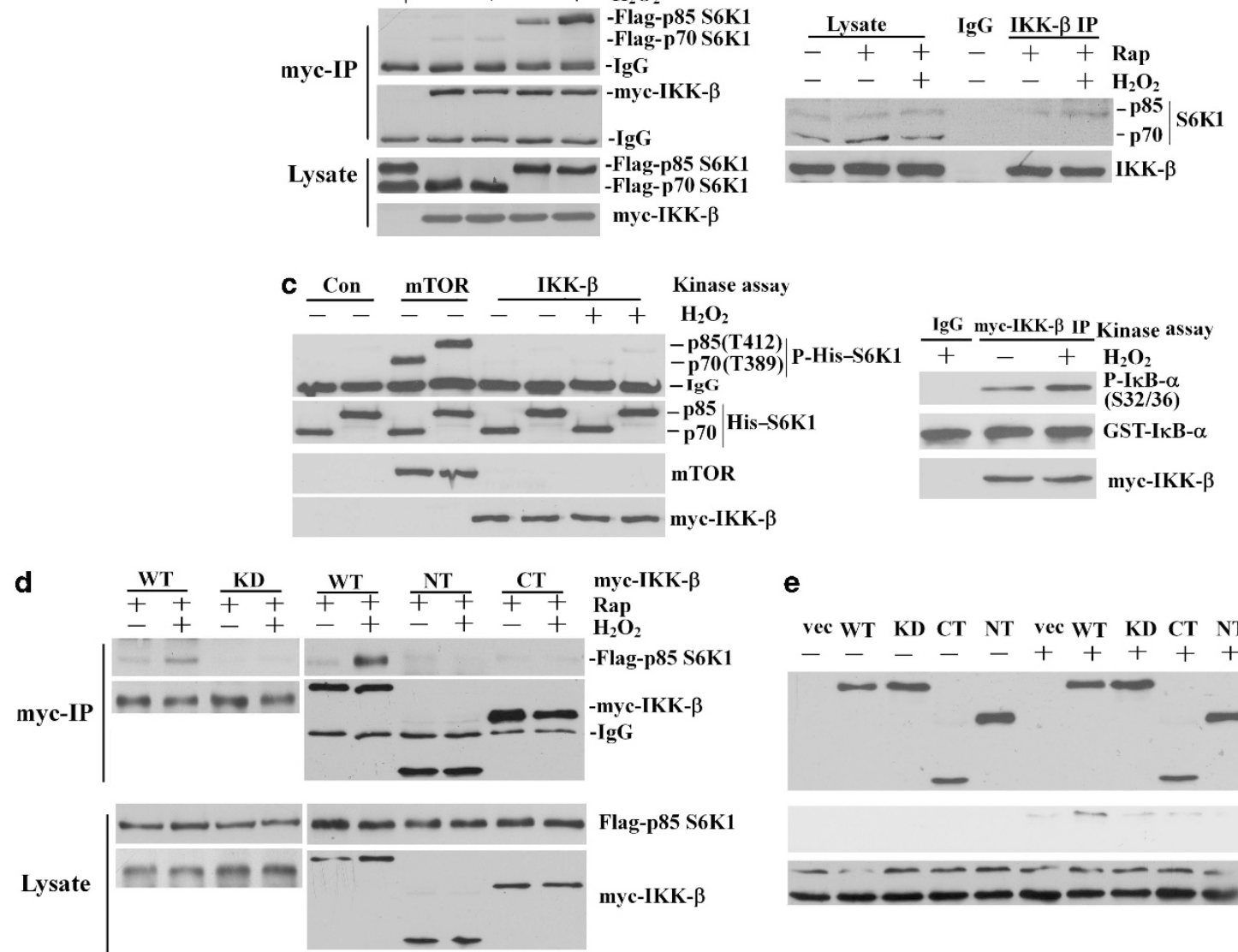

e

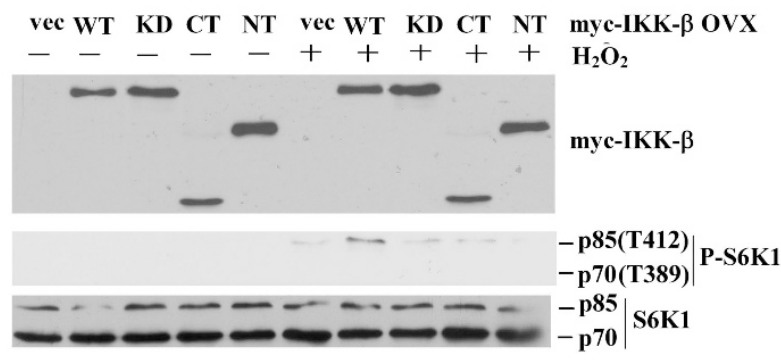

Figure 5 Association of IKK- $\beta$ with p85 S6K1 is required for $\mathrm{H}_{2} \mathrm{O}_{2}$-induced $\mathrm{p} 86 \mathrm{~S} 6 \mathrm{~K} 1$ activation. (a) MCF-7 cells co-transfected with flag-p85-S6K1 and myc-IKK- $\beta$ were incubated with $100 \mathrm{nM}$ rapamycin for $30 \mathrm{~min}$ followed by $1 \mathrm{mM}$ of $\mathrm{H}_{2} \mathrm{O}_{2}$ for another $30 \mathrm{~min}$. Cells were then lysed and cell lysates were immunoprecipitated with myc antibody. Co-purified flag-p85 S6K1 and myc-IKK- $\beta$ were detected by immunoblotting. (b) MCF-7 cells incubated with rapamycin and $\mathrm{H}_{2} \mathrm{O}_{2}$ as in (a). Lysates from the cells were precipitated with anti-IKK- $\beta$ antibody. The precipitates were assayed for co-purified S6K1 by immunoblotting. (c) IKK- $\beta$ does not phosphorylate p85 S6K1 (T412) in vitro. MCF7 cells transfected with empty vectors or myc-IKK- $\beta$ were stimulated with or without $1 \mathrm{mM}$ of $\mathrm{H}_{2} \mathrm{O}_{2}$ for $30 \mathrm{~min}$. Cells were then lysed and lysates immunoprecipitated with antimTOR or myc antibodies. The precipitated mTOR or myc-IKK- $\beta$ was assayed for kinase activity against recombinant His-p70/85 S6K1 and GST-I $\kappa$ B- $\alpha$ in vitro. (d) IKK- $\beta$ kinase activity is required for its association with p85 S6K1. MCF-7 cells co-transfected with flag-p85-S6K1 and myc-IKK- $\beta$ (WT) or the kinase-dead mutant (KD), C-terminal (CT) (291-756 aa) or N-terminal (NT) (1-308 aa) of IKK- $\beta$ were treated as in (a) and co-purified flag-p85 S6K1 and myc-IKK- $\beta$ were detected by immunoblotting. (e) MCF-7 cells were transfected with IKK- $\beta$ siRNA for $36 \mathrm{~h}$, followed by transfection with empty vector (vec), IKK- $\beta$ WT, KD, CT or NT for $24 \mathrm{~h}$ and incubated with $100 \mathrm{nM}$ rapamycin and $\mathrm{H}_{2} \mathrm{O}_{2}$ as in (a) lysates from the cells were analyzed by immunoblotting for the levels of IKK- $\beta$, phospho-p70/85 (T389/412) S6K1, p70/85 S6K1. OVX, overexpression

is mediated by $\mathrm{p} 85 \mathrm{~S} 6 \mathrm{~K} 1$, which in response to oxidative stress, phosphorylates Mdm2 (S166) and induces p53 accumulation.

Activation of the mTORC1 pathway is generally involved in cell survival and proliferation. ${ }^{23,33,34}$ However, several recent studies demonstrate a pro-apoptotic role of the pathway. ${ }^{25-27}$ In primary neuron and HeLa cells, mTORC1 was found to promote apoptosis induced by various toxic stimuli. ${ }^{27} \mathrm{Simi}-$ larly, in MEF cells, a reduced mTORC1 activity by expression of tuberous sclerosis complex was able to protect the cells from endoplasmic reticulum stress-induced apoptosis. Interestingly, in the latter case, the protective effect of mTORC1 appeared to be insensitive to rapamycin. ${ }^{26} \mathrm{~A}$ recent study into the mechanism underlying the pro-apoptotic role of mTORC1 identified Mdm2 as a direct target of S6K1, which interacts with and phosphorylates Mdm2 at S163, causing Mdm2 cytoplasmic retention and p53 accumulation in response to genotoxic stress in MEFs. ${ }^{25}$ Although some studies showed that phosphorylation of Mdm2 at S163 promoted Mdm2 nuclear import, others failed to observe such a phenomenon. ${ }^{35-39}$ This mTORC1-enhanced S6K1-Mdm2 complex formation and S6K1-mediated Mdm2 phosphorylation are hence believed to be responsible for the pro-apoptotic role of mTORC1 under genotoxic stress conditions. However, the pro-death effect of mTORC1 appeared to be cell specific, as it was not observed in some cancer cell lines, including HeLa and HCT116. ${ }^{25,40,41}$ In the present study, we found that S6K1 knockdown protected the cells from $\mathrm{H}_{2} \mathrm{O}_{2}$-induced cell death in MCF-7, HeLa and HCT116. The pro-death effect of S6K1 in MCF-7 cells was independent of MTORC1, because neither rapamycin treatment nor knockdown of mTOR, Raptor and Rheb protected the cells from oxidative stress-induced cell death. Instead, we found that activation of $\mathrm{p} 85$, but not p70 S6K1, was responsible for the $\mathrm{H}_{2} \mathrm{O}_{2}$-induced cell death. Our results demonstrate that p85 S6K1, upon activation, phosphorylates Mdm2 at $\mathrm{S} 163$ and promotes p53 accumulation. This p53-dependent mechanism is likely to underlie the prodeath role of p85 S6K1 during oxidative stress and may help to 


\section{a}

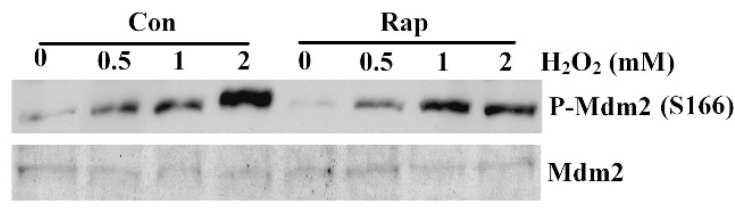

b

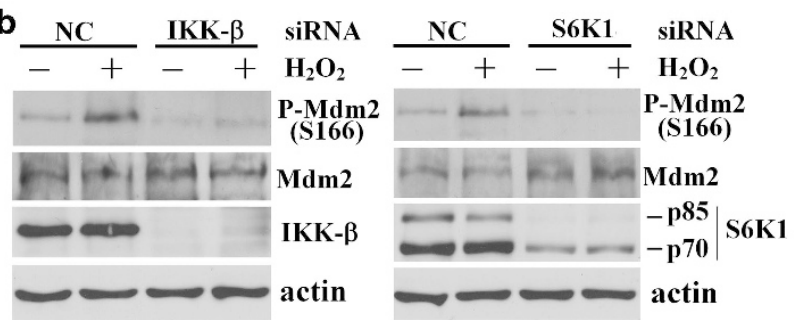

C
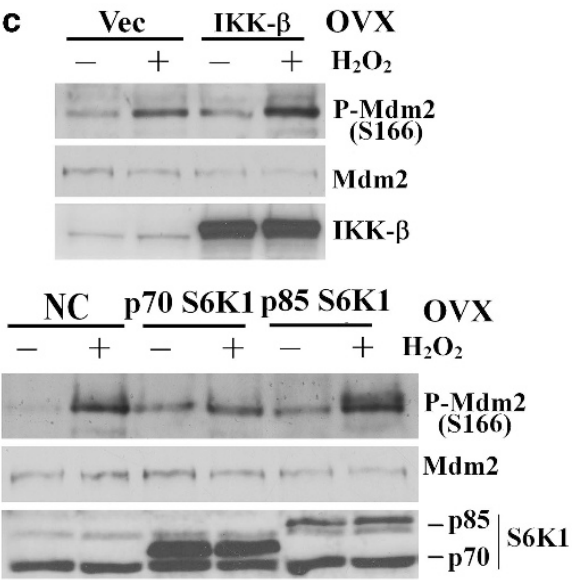

Figure 6 IKK- $\beta$ and p85 S6K1 mediate $\mathrm{H}_{2} \mathrm{O}_{2}$-induced phosphorylation of $\mathrm{Mdm} 2$ (S166). (a) $\mathrm{H}_{2} \mathrm{O}_{2}$ stimulates phosphorylation of $\mathrm{Mdm} 2$ at $\mathrm{S} 166$ in a rapamycin-insensitive way. MCF-7 cells were incubated with $100 \mathrm{nM}$ of rapamycin for 30 min followed by stimulation with various concentrations of $\mathrm{H}_{2} \mathrm{O}_{2}$ for $1 \mathrm{~h}$. Levels of phospho-Mdm2 ( $\left.\mathrm{S} 166\right)$ and Mdm2 were detected by immunoblotting. (b) IKK- $\beta$ or S6K1 knockdown reduces $\mathrm{H}_{2} \mathrm{O}_{2}$-stimulated phospho-Mdm2 (S166). MCF-7 cells transfected with IKK- $\beta$ or S6K1 or negative control (NC) siRNA were assayed for the levels of phospho-Mdm2 (S166) by immunoblotting. (c) IKK- $\beta$ or S6K1 overexpression (OVX) enhances $\mathrm{H}_{2} \mathrm{O}_{2}$-induced phosphorylation of Mdm2 at S166. Cells transfected with HA-IKK- $\beta$, flag-p70 or p85 S6K1 were stimulated with $1 \mathrm{mM} \mathrm{of} \mathrm{H}_{2} \mathrm{O}_{2}$ for $1 \mathrm{~h}$. The levels of phospho-Mdm2 (S166), Mdm2, IKK- $\beta$ and $p 70 / 85$ S6K1 were assayed by immunoblotting

explain the mTORC1-independent role of S6K1 in doxorubicin-induced cell death observed in previous studies. ${ }^{25,40,41}$

Both p70 and p85 S6K1 are downstream effectors of mTORC1. Previous studies have demonstrated that the two isoforms are concordantly activated in an mTORC1-dependent manner. ${ }^{42,43}$ But a recent report has demonstrated that p85 S6K1, but not p70 S6K1, could be activated by phosphatidic acid in an $\mathrm{mTORC} 1 /$ rapamycin-independent way. ${ }^{44}$ p85 S6K1 was also previously found to primarily localize to the nucleus. ${ }^{17,45}$ However, recent studies have shown that this kinase also functions in the cytoplasm. ${ }^{46,47}$ Consistent with these recent observations, we found that p85 S6K1 exists predominantly in the cytoplasm. In addition, our results also indicate that the two isoforms can be differentially activated by TNF- $\alpha$ and $\mathrm{H}_{2} \mathrm{O}_{2}$ in an mTORC1-independent manner. Taken together, it is implicated that p70 and p85 S6K1 differ not only in localization, but also in regulation and function.

TNF- $\alpha$ and $\mathrm{H}_{2} \mathrm{O}_{2}$ treatments activate $\mathrm{p} 85 \mathrm{~S} 6 \mathrm{~K} 1$ by inducing its phosphorylation at T412. This phosphorylation is blocked by inhibition of IKK or specifically knockdown of IKK- $\beta$, suggesting that the phosphorylation is mediated mainly by IKK- $\beta$. Although IKK has been implicated in mTORC1 regulation through direct phosphorylation of tuberous sclerosis complex 1 , we found that inhibition of mTOR by rapamycin or ATP-competitive kinase inhibitor has little effect on the TNF- $\alpha$ and $\mathrm{H}_{2} \mathrm{O}_{2}$-induced phosphorylation of $\mathrm{p} 85 \mathrm{~S} 6 \mathrm{~K} 1$. This finding rules out the involvement of $\mathrm{mTOR}$ in the process. On the other hand, our finding that IKK- $\beta$ associates with p85 S6K1 raises the possibility that IKK- $\beta$ is able to directly phosphorylate p85 S6K1. Despite this finding, we are unable to detect a direct phosphorylation of p85 S6K1 (T412) by IKK$\beta$ in our in vitro kinase assay, which indicates that alternative kinases may direct the $\mathrm{H}_{2} \mathrm{O}_{2}$-induced phsophorylation of p85 S6K1. As a recent study has revealed IKK- $\beta$ as an adaptor in UV-induced $I_{\kappa} \mathrm{B}-\alpha$ ubiquitination, ${ }^{32}$ our results implicate that IKK- $\beta$ may act as a scaffold protein to recruit other kinases that are responsible for phosphorylation of p85 S6K1 upon
$\mathrm{H}_{2} \mathrm{O}_{2}$ stimulation. The kinase activity of IKK- $\beta$ is required for its association with p85 S6K1 and the activation of p85 S6K1.

In summary, our study reveals a novel oxidative stressresponsive pathway that involves IKK- $\beta$, p85 S6K1, Mdm2 and p53. Through this novel pathway, the oxidative stimulus drives IKK- $\beta$ to activate p85 S6K1 independent of mTORC1. The activated p85 S6K1 in turn induces cell death through a mechanism involving phosphorylation of Mdm2 and induction of $\mathrm{p} 53$. Our results demonstrating that IKK- $\beta$ has a role in promoting cell death adds another level of complexity to IKK- $\beta$ regulation and function, which should be taken into consideration when IKK inhibitors are used in therapeutic treatments.

\section{Materials and Methods}

Chemicals and antibodies. Chemicals used in the study include: Pp242 (Active Biochemicals, Hongkong, China); Bay 11-7082 and Wedelolactone (Calbiochem, Darmstadt, Germany); Rapamycin, MG132, insulin and human recombinant TNF- $\alpha$ (Sigma, St. Louis, MO, USA); LY294002 (Cell Signaling, Beverly, MA, USA).

The following antibodies were used: flag (cat\# F1804) (Sigma); phospho-p70/85S6K1 (T389/412) (cat\# 9206), 4E-BP1 (cat\# 9644), phospho-4E-BP1 (T37/46) (cat\# 2855), phospho-S6 (S235/236) (cat\# 4856), IKK- $\alpha$ (cat\# 2682), IKK- $\beta$ (cat\# 2678), phospho-IKK $\alpha / \beta$ (S176/180) (cat\# 2694), Raptor (cat\# 2280) and P-Mdm2 (S166) (cat\# 3521) (Cell Signaling); S6 (cat\# 74459), actin (cat\# 47778), mTOR (cat\# 1549), p65 (cat\# 71677), Mdm2 (cat\# 965), p53 (cat\# 74573), p70-S6K (cat\# 8418) and GFP (cat\# 101536) (Santa Cruz Biotechnology Inc., Santa Cruz, CA, USA); myc (cat\# ALX-804-627) (Enzo Life Sciences, Farmingdale, NY, USA); Histone H2A.X (cat\# BS2984) and $\beta$-tubulin (cat\# BS1482) (Bioworld Technology Inc., Louis Park, MN, USA); Rheb (cat\# 25873) (Abcam, Cambridge, UK); IKK- $\gamma$ (cat\# 18474-1-AP) (ProteinTech Group Inc., Chicago, IL, USA).

Plasmids and preparation of GST-S6 and His-P70/85 S6K1 proteins. HA-IKK- $\alpha$, HA-IKK- $\beta$, myc-IKK- $\alpha$, myc-IKK- $\beta$ and IKK- $\beta$ kinase-dead (IKK- $\beta$ KD) vectors were kindly provided by Dr. Gutian Xiao (University of Pittsburgh School of Medicine, Pittsburgh, PA, USA). The sequences encoding the C-terminal (291-756 aa) and N-terminal (1-308 aa) of IKK- $\beta$ were sub-cloned into pUSEamp $(+)$ vector (myc-his tag).

To generate plasmids that express only p85 S6k1, the sequence for the N-terminal 23 amino acids of p85 S6K1 was added to rat p70-S6K1 CDNA 

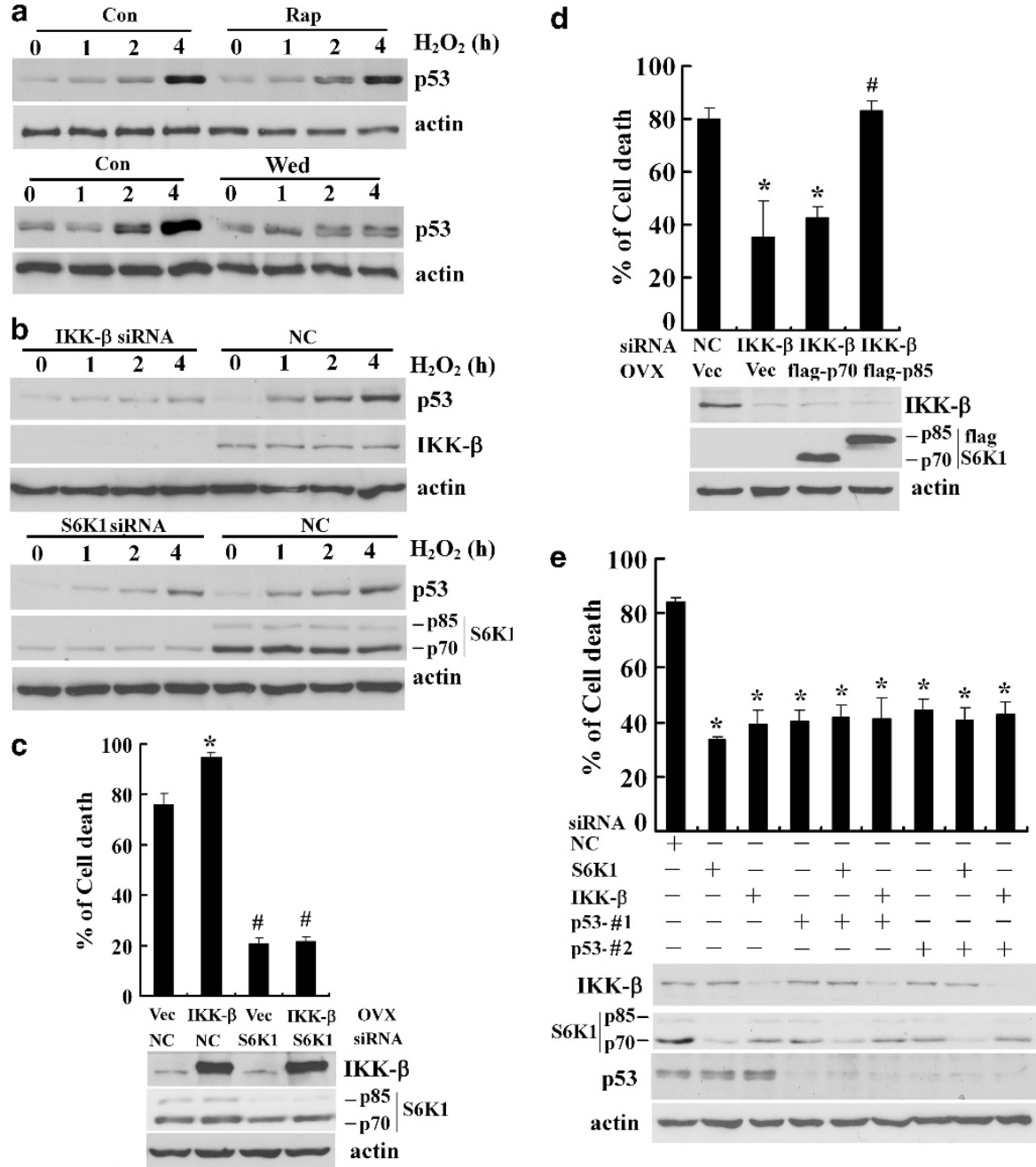

Figure 7 IKK- $\beta$ mediates $\mathrm{H}_{2} \mathrm{O}_{2}$-induced cell death via activation of the p85 S6K1-Mdm2-p53 pathway. (a) $\mathrm{H}_{2} \mathrm{O}_{2}$ induces p53 expression in a rapamycin-insensitive and IKK-dependent manner. MCF-7 cells were incubated with $100 \mathrm{nM}$ of rapamycin or wedelolactone (Wed) for $30 \mathrm{~min}$ followed by stimulation with $1 \mathrm{mM}$ of $\mathrm{H}_{2} \mathrm{O}_{2}$ for various times. Levels of p53 were examined by immunoblotting. (b) IKK- $\beta$ or S6K1 knockdown reduces $\mathrm{H}_{2} \mathrm{O}_{2}$-induced p53 accumulation. MCF-7 cells transfected with IKK- $\beta$ or S6K1 or negative control (NC) siRNA were stimulated with $1 \mathrm{mM}$ of $\mathrm{H}_{2} \mathrm{O}_{2}$ for indicated times. Levels of $p 53$, IKK- $\beta$ and S6K1 were examined by immunoblotting. (c) p85 S6K1 is required for IKK- $\beta$-mediated cell death. MCF-7 cells were co-transfected with S6K1 or control siRNA and HA-IKK- $\beta$ or control vector. After treatment with $1 \mathrm{mM} \mathrm{H} \mathrm{H}_{2} \mathrm{O}_{2}$ for $36 \mathrm{~h}$, cells were assayed for cell viability. ${ }^{*} P<0.05$ compared with vector control. ${ }^{\#} P<0.05$ compared with NC control. OVX, overexpression. (d) MCF-7 cells were co-transfected with IKK- $\beta$ siRNA and flag-p70, p85 S6K1 or control vectors. After treatment with $1 \mathrm{mM} \mathrm{H}_{2} \mathrm{O}_{2}$ for $36 \mathrm{~h}$, cells were assayed for cell viability. ${ }^{*} P<0.05$ compared with $\mathrm{NC}$ control. ${ }^{\#} P<0.05$ compared with p70 S6K1 and vector control. (e) p53 contributes to IKK- $\beta$ - and p85 S6K1-mediated cell death. MCF-7 cells were co-transfected with p53 and IKK- $\beta$ or $\mathrm{S} 6 \mathrm{~K} 1$ siRNAs. After treatment with $1 \mathrm{mM} \mathrm{H}_{2} \mathrm{O}_{2}$ for $48 \mathrm{~h}$, cells were assayed for cell viability. Levels of $p 53$, IKK- $\beta$ and S6K1 were examined by immunoblotting. ${ }^{*} P<0.05$ compared with NC control

(pRK-7-p70 S6K1) (Addgene, Cambridge, MA, USA) by PCR and the p70 S6K1 translation starting site (70-72th bp, ATG) was changed into TTG. Both p70 S6K1 and p85 S6K1 cDNAs were sub-cloned into pcDNA3.1-Flag, pEGFP-C1 and PET-28a vectors. Human 40S ribosomal protein S6 CDNA was obtained from HEK293 cells by RT-PCR and was sub-cloned into prokaryotic expression vector pGEX-6P1(pGEX-6P-1-S6). GST-S6, His-p70 S6K1 and His-p85 S6K1 proteins were induced by isopropyl $\beta$-D-1-thiogalactopyranoside and purified using glutathoine-agarose or Ni-NAT agarose beads. Purified GST-S6 and His-p70/85 S6K1 proteins were used as substrates for S6K1 or mTORC1, IKK- $\beta$ in vitro kinase assay.

Cell culture and transfection. MCF-7, HeLa, HEK293 and HCT116 cells were purchased from American Type Culture Collection (Manassas, VA, USA) and cultured in high glucose DMEM (Life Technologies Corporation, Carlsbad, CA, USA) supplemented with $10 \% \mathrm{FBS}$ in a humidified atmosphere of $5 \% \mathrm{CO}_{2}$. For transient transfection, HEK293 or MCF-7 cells were transfected with plasmid
DNAs using lipofectamine 2000 (Invitrogen, Carlsbad, CA, USA) following the manufacturer's instruction.

RNA interference. Negative control siRNAs, IKK- $\alpha$, IKK- $\beta$, IKK- $\gamma$, mTOR, Raptor, Rheb, p53, p65 and p70/85 S6K1-specific siRNA were chemically synthesized by GenePharma Co., Ltd (Shanghai, China). The sequences of these siRNAs are the following:

IKK- $\alpha \# 1$ : 5'-GCAGGCUCUUUCAGGGACA-3'; IKK- $\alpha$ \#2: 5'-CAAAGAAGCUGA CAAUACU-3';

IKK- $\beta \# 1$ : $5^{\prime}$-CAGGUGAGCAGAUUGCCAU-3'; IKK- $\beta$ \#2: $5^{\prime}$-GGUGGAAGAGG UGGUGAGC-3';

IKK- $\gamma$ \#1: $5^{\prime}$-ACAGGAGGUGAUCGAUAAG-3'; IKK- $\gamma$ \#2: $5^{\prime}$-AACAGGAGGUG AUCGAUAA-3';

S6K1 \#1: 5'-GGACUUCCGAGACAGGGAATT-3'; S6K \#2: 5'-AAACACUCCU GCCAUGUCC-3'; 
p53 \#1: 5'-CAGTCTACCTCCCGCCATA-3'; p53 \#2, 5'-GAAGAAACCACTGG ATGGA-3';

mTOR: 5'-GAGCCUUGUUGAUCCUUAATT-3'; Rheb: 5'-CGGGCAAGAUGA AUAUUCUTT-3';

p65: 5'-GCCCUAUCCUUUACGUCA-3'.

Cells were transfected with the siRNAs at $60 \%$ confluence using lipofectamine 2000 (Invitrogen), following the manufacturer's instructions.

Immunoprecipitation and western blot. To detect the association of endogenous IKK- $\beta$ with $p 85$ S6K1, MCF-7 cells grown in $6 \mathrm{~cm}$ dishes treated with rapamycin and $\mathrm{H}_{2} \mathrm{O}_{2}$ were rinsed twice with PBS, and lysed with $400 \mu \mathrm{l}$ of ice-cold lysis buffer (40 mM HEPES, pH 7.5, $120 \mathrm{mM} \mathrm{NaCl}, 1 \mathrm{mM}$ EDTA, $10 \mathrm{mM}$ pyrophosphate, $10 \mathrm{mM}$ glycerophosphate, $50 \mathrm{mM} \mathrm{NaF}, 1.5 \mathrm{mM} \mathrm{Na}_{3} \mathrm{VO}_{4}, 1 \%$ Triton $\mathrm{X}-100$, and $1 \times$ EDTA-free protease inhibitors) on ice for $30 \mathrm{~min}$, followed by centrifugation at $12000 \times \mathrm{g}$ for $10 \mathrm{~min}$. Supernatants were incubated with $4 \mu \mathrm{g}$ of anti-IKK- $\beta$ antibody overnight at $4{ }^{\circ} \mathrm{C}$ on a nutator, followed by addition of $30 \mu \mathrm{l}$ of $50 \%$ slurry of protein G Sepharose (Amersham Phamacia, Cincinnati, OH, USA) beads for another $2 \mathrm{~h}$. Beads were then washed four times with lysis buffer and used for immunoblotting analysis.

To detect the association of overexpressed myc-IKK- $\beta$ with flag-p70/85 S6K1, HEK293 cells were grown in $6 \mathrm{~cm}$ dishes and co-transfected with myc-IKK- $\beta$ wt, IKK- $\beta$ KN, IKK- $\beta$ (1-308) or IKK- $\beta$ (291-756) and flag-p70/85 S6K1 plasmids. Twenty-four hours later, cells were treated and lysed, as described above, and lysates were precipitated with anti-myc antibody. Precipitated proteins were then analyzed by immunoblotting.

In vitro kinase assay for S6K1, mTORC1 and IKK- $\beta$. For S6K1 in vitro kinase assay, HEK293 cells transfected with flag-p70 or flag-p85 S6K1 were lysed with lysis buffer and lysates were incubated with anti-flag antibody for $3 \mathrm{~h}$ at $4{ }^{\circ} \mathrm{C}$, followed by incubation with protein $\mathrm{G}$ Sepharose beads for another $2 \mathrm{~h}$. Beads were washed four times with lysis buffer and once with kinase buffer ( $50 \mathrm{mM}$ Tris-Cl, $\mathrm{pH} 7.4,0.5 \mathrm{mM}$ dithiothreitol, $10 \mathrm{mM} \mathrm{MgCl}$ ). Four micrograms of purified GST-S6 was added to a $20 \mu$ l kinase reaction mixture $(10 \mathrm{mM}$ ATP, $50 \mathrm{mM}$ Tris-Cl, pH 7.4, $0.5 \mathrm{mM}$ dithiothreitol, $10 \mathrm{mM} \mathrm{MgCl}$ ). After $30 \mathrm{~min}$ of incubation at room temperature, the reaction was stopped by the addition of $2 \times$ SDS sample buffer followed by boiling for $5 \mathrm{~min}$.

mTORC1 or IKK- $\beta$ in vitro kinase assay were performed, as previously described. ${ }^{48}$ Endogenous mTORC1 was immunopurified from HEK293 cells. IKK- $\beta$ was immunopurified from HEK293 cells transfected with myc-IKK- $\beta$. Cells were lysed in ice-cold buffer ( $40 \mathrm{mM}$ HEPES (pH 7.4), $2 \mathrm{mM}$ EDTA, $10 \mathrm{mM}$ pyrophosphate, $10 \mathrm{mM}$ glycerophosphate, $0.3 \%$ CHAPS, and one tablet of EDTA-free protease inhibitors (Roche, Basel, Switzerland) per $25 \mathrm{ml}$ ). Supernatants were incubated with anti-mTOR or myc antibody for $2 \mathrm{~h}$ at $4{ }^{\circ} \mathrm{C}$, followed by addition of $30 \mu \mathrm{l}$ of $50 \%$ slurry of protein $\mathrm{G}$ Sepharose beads for another $1 \mathrm{~h}$. Beads were then washed four times with lysis buffer and once kinase buffer (mTORC1 kinase buffer: $25 \mathrm{mM}$ HEPES (pH 7.4), $50 \mathrm{mM} \mathrm{KCl}, 10 \mathrm{mM} \mathrm{MgCl} 2,250 \mu \mathrm{M}$ ATP; IKK- $\beta$ kinase buffer: $20 \mathrm{mM}$ HEPES (pH 7.7), $20 \mathrm{mM} \beta$-glycerophosphate, $10 \mathrm{mM} \mathrm{MgCl}, 10 \mathrm{mM}$ PNPP, $100 \mu \mathrm{M} \mathrm{Na}_{3} \mathrm{VO}_{4}$, $2 \mathrm{mM}$ DTT, $1 \mathrm{mM}$ ATP, $10 \mu \mathrm{g} / \mathrm{ml}$ approtonin, $50 \mathrm{mM} \mathrm{NaCl}$ ). Four micrograms of purified His-p70 S6K1, p85 S6K1 or GST-IkB- $\alpha$ (Millipore, Billerica, MA, USA) were added to $30 \mu \mathrm{l}$ kinase buffer. Kinase assays were performed for $30 \mathrm{~min}$ at $30^{\circ} \mathrm{C}$, and terminated by the addition of the $2 \times$ SDS sample buffer.

Cell viability analysis. After each treatment, the number of viable cells was counted by trypan blue dye exclusion using a hemocytometer. The dead cell ratio $=$ trypan blue-stained cells/total cells $\times 100 \%$

Nuclear-cytoplasmic fractionation. Nuclear and cytosolic fractions were isolated as described previously. ${ }^{25}$ Briefly cultured cells were washed twice with cold PBS, lysed with ice-cold lysis buffer containing $10 \mathrm{mM}$ Tris, pH 7.9, $10 \mathrm{mM}$ $\mathrm{KCl}, 2 \mathrm{mM} \mathrm{MgCl}, 0.1 \mathrm{mM}$ EDTA and $0.7 \%$ Nonidet P-40. After incubation on ice for $10 \mathrm{~min}$, lysates were centrifuged at $500 \times \mathrm{g}$ for $5 \mathrm{~min}$. The supernatant was collected as the cytosolic fraction, and the pellet was re-suspended in buffer containing $40 \mathrm{mM}$ Tris, $\mathrm{pH} 7.9,350 \mathrm{mM} \mathrm{NaCl}, 2 \mathrm{mM} \mathrm{MgCl}, 1 \mathrm{mM}$ EDTA, $0.2 \mathrm{mM}$ EGTA, $20 \%$ glycerol, $1 \%$ Nonidet P-40, $1 \mathrm{mM}$ phenylmethylsulfonyl fluoride, $2 \mathrm{mM}$ dithiothreitol, $2 \mu \mathrm{g} / \mathrm{ml}$ leupeptin and $1 \mu \mathrm{g} / \mathrm{ml}$ aprotinin on ice for $20 \mathrm{~min}$ and harvested by centrifugation at $12000 \times \mathrm{g}$ for $10 \mathrm{~min}$ at $4^{\circ} \mathrm{C}$. The purity of the nuclear and cytosolic fractions was assessed by immunoblotting extracts and the isolated fractions with antibodies against nuclear protein Histone H2A.X and cytosol protein $\beta$-tubulin.
Immunofluorescence and confocal microscopy. Cells plated on chamber slides were fixed with $4 \%$ paraformaldehyde, permeabilized with $0.2 \%$ Triton X-100, and incubated with the primary antibody at $4{ }^{\circ} \mathrm{C}$ overnight. Chamber slides were subsequently incubated with fluorescein isothiocyanate (FITC)- or (tetramethyl Rhodamine Iso-thiocyanate) TRITC-conjucated secondary antibody for $1 \mathrm{~h}$ at room temperature. The slides were mounted in ProLong Gold Antifade Reagent with 4, 6-diamidino- 2-phenylindole dihydrochloride (DAPI) (Invitrogen) and imaged with a Nikon Eclipse E400 fluorescent microscope (Nikon Corporation, Tokyo, Japan).

\section{Conflict of Interest}

The authors declare no conflict of interest.

Acknowledgements. We thank Dr. Jian Yang and Dr. Richard T Tran for critical review of the paper. The work was supported by National Natural Sciences Foundation of China (30900555, 31000633 and 91029727), Program for Changjiang Scholars and Innovative Research Team in University (IRT1142) and the State Key Development Program for Basic Research of China (2009CB 918904).

1. Weinberg $F$, Chandel NS. Reactive oxygen species-dependent signaling regulates cancer. Cell Mol Life Sci 2009; 66: 3663-3673.

2. Veal EA, Day AM, Morgan BA. Hydrogen peroxide sensing and signaling. Mol Cell 2007; 26: $1-14$

3. Hayden MS, Ghosh S. Shared principles in NF-kappaB signaling. Cell 2008; 132: 344-362.

4. Perkins ND. Integrating cell-signalling pathways with NF-kappaB and IKK function. Nat Rev Mol Cell Biol 2007; 8: 49-62.

5. Gloire G, Charlier E, Rahmouni S, Volanti C, Chariot A, Erneux C et al. Restoration of SHIP-1 activity in human leukemic cells modifies NF-kappaB activation pathway and cellular survival upon oxidative stress. Oncogene 2006; 25: 5485-5494.

6. Gloire G, Legrand-Poels S, Piette J. NF-kappaB activation by reactive oxygen species: fifteen years later. Biochem Pharmacol 2006; 72: 1493-1505.

7. Liu Q, Kou JP, Yu BY. Ginsenoside Rg1 protects against hydrogen peroxide-induced cell death in PC12 cells via inhibiting NF-kappaB activation. Neurochem Int 2011; 58: 119-125.

8. Takada Y, Mukhopadhyay A, Kundu GC, Mahabeleshwar GH, Singh S, Aggarwal BB. Hydrogen peroxide activates NF-kappa B through tyrosine phosphorylation of I kappa B alpha and serine phosphorylation of p65: evidence for the involvement of I kappa B alpha kinase and Syk protein-tyrosine kinase. J Biol Chem 2003; 278: 24233-24241.

9. Korn SH, Wouters EF, Vos N, Janssen-Heininger YM. Cytokine-induced activation of nuclear factor-kappa $B$ is inhibited by hydrogen peroxide through oxidative inactivation of IkappaB kinase. J Biol Chem 2001; 276: 35693-35700.

10. Fujioka S, Schmidt C, Sclabas GM, Li Z, Pelicano H, Peng B et al. Stabilization of p53 is a novel mechanism for proapoptotic function of NF-kappaB. J Biol Chem 2004; 279 : 27549-27559.

11. Jennewein C, Karl S, Baumann B, Micheau O, Debatin KM, Fulda S. Identification of a novel pro-apoptotic role of NF-kappaB in the regulation of TRAIL- and CD95-mediated apoptosis of glioblastoma cells. Oncogene 2011; 31: 1468-1474.

12. Ho JQ, Asagiri M, Hoffmann A, Ghosh G. NF-kappaB potentiates caspase independent hydrogen peroxide induced cell death. PLOS One 2011; 6: e16815.

13. Zoncu R, Efeyan A, Sabatini DM. mTOR: from growth signal integration to cancer, diabetes and ageing. Nat Rev Mol Cell Biol 2011; 12: 21-35.

14. Selman C, Tullet JM, Wieser D, Irvine E, Lingard SJ, Choudhury Al et al. Ribosomal protein S6 kinase 1 signaling regulates mammalian life span. Science 2009; 326: 140-144.

15. Sengupta S, Peterson TR, Sabatini DM. Regulation of the mTOR complex 1 pathway by nutrients, growth factors, and stress. Mol Cell 2010; 40: 310-322.

16. Cheatham L, Monfar M, Chou MM, Blenis J. Structural and functional analysis of pp70S6k. Proc Natl Acad Sci USA 1995; 92: 11696-11700.

17. Reinhard C, Fernandez A, Lamb NJ, Thomas G. Nuclear localization of p85s6k: functional requirement for entry into S phase. EMBO J 1994; 13: 1557-1565.

18. Pearce LR, Komander D, Alessi DR. The nuts and bolts of AGC protein kinases. Nat Rev $\mathrm{Mol}$ Cell Biol 2010; 11: 9-22.

19. Pullen N, Dennis PB, Andjelkovic M, Dufner A, Kozma SC, Hemmings BA et al. Phosphorylation and activation of p70s6k by PDK1. Science 1998; 279: 707-710.

20. Hellerbrand C, Jobin C, limuro Y, Licato L, Sartor RB, Brenner DA. Inhibition of NFkappaB in activated rat hepatic stellate cells by proteasome inhibitors and an IkappaB super-repressor. Hepatology 1998; 27: 1285-1295.

21. Chariot A. The NF-kappaB-independent functions of IKK subunits in immunity and cancer. Trends Cell Biol 2009; 19: 404-413.

22. Lee DF, Kuo HP, Chen CT, Hsu JM, Chou CK, Wei Y et al. IKK beta suppression of TSC1 links inflammation and tumor angiogenesis via the mTOR pathway. Cell 2007; 130 : 440-455.

23. Inoki K, Zhu T, Guan KL. TSC2 mediates cellular energy response to control cell growth and survival. Cell 2003; 115: 577-590. 
24. Park KK, Liu K, Hu Y, Smith PD, Wang C, Cai B et al. Promoting axon regeneration in the adult CNS by modulation of the PTEN/mTOR pathway. Science 2008; 322: 963-966.

25. Lai KP, Leong WF, Chau JF, Jia D, Zeng L, Liu $\mathrm{H}$ et al. S6K1 is a multifaceted regulator of Mdm2 that connects nutrient status and DNA damage response. EMBO J 2010; 29: 2994-3006.

26. Kang YJ, Lu MK, Guan KL. The TSC1 and TSC2 tumor suppressors are required for proper ER stress response and protect cells from ER stress-induced apoptosis. Cell Death Differ 2011; 18: 133-144.

27. Karassek S, Berghaus C, Schwarten M, Goemans CG, Ohse N, Kock G et al. Ras homolog enriched in brain (Rheb) enhances apoptotic signaling. J Biol Chem 2010; 285 : 33979-33991.

28. Ruvinsky I, Meyuhas O. Ribosomal protein $\mathrm{S} 6$ phosphorylation: from protein synthesis to cell size. Trends Biochem Sci 2006; 31: 342-348.

29. Li M, Zhao L, Liu J, Liu A, Jia C, Ma D et al. Multi-mechanisms are involved in reactive oxygen species regulation of mTORC1 signaling. Cell Signal 2010; 22: 1469-1476.

30. Dan HC, Adli M, Baldwin AS. Regulation of mammalian target of rapamycin activity in PTEN-inactive prostate cancer cells by I kappa B kinase alpha. Cancer Res 2007; 67: 6263-6269.

31. Dan HC, Baldwin AS. Differential involvement of IkappaB kinases alpha and beta in cytokine- and insulin-induced mammalian target of rapamycin activation determined by Akt. J Immunol 2008; 180: 7582-7589.

32. Tsuchiya Y, Asano T, Nakayama K, Kato T Jr., Karin M, Kamata H. Nuclear IKKbeta is an adaptor protein for IkappaBalpha ubiquitination and degradation in UV-induced NF-kappaB activation. Mol Cell 2010; 39: 570-582.

33. Manfredi JJ. The Mdm2-p53 relationship evolves: Mdm2 swings both ways as an oncogene and a tumor suppressor. Genes Dev 2010; 24: 1580-1589.

34. Li Y, Wang Y, Kim E, Beemiller P, Wang CY, Swanson J et al. Bnip3 mediates the hypoxiainduced inhibition on mammalian target of rapamycin by interacting with Rheb. J Biol Chem 2007; 282: 35803-35813.
35. Mayo LD, Donner DB. A phosphatidylinositol 3-kinase/Akt pathway promotes translocation of Mdm2 from the cytoplasm to the nucleus. Proc Natl Acad Sci USA 2001; 98: 11598-11603.

36. Zhou BP, Liao Y, Xia W, Zou Y, Spohn B, Hung MC. HER-2/neu induces p53 ubiquitination via Akt-mediated MDM2 phosphorylation. Nat Cell Biol 2001; 3: 973-982.

37. Weber HO, Ludwig RL, Morrison D, Kotlyarov A, Gaestel M, Vousden KH. HDM2 phosphorylation by MAPKAP kinase 2. Oncogene 2005; 24: 1965-1972.

38. Malmlof M, Roudier E, Hogberg J, Stenius U. MEK-ERK-mediated phosphorylation of $\mathrm{Mdm} 2$ at Ser-166 in hepatocytes. Mdm2 is activated in response to inhibited Akt signaling. J Biol Chem 2007; 282: 2288-2296.

39. Hogan C, Hutchison C, Marcar L, Milne D, Saville M, Goodlad J et al. Elevated levels of oncogenic protein kinase Pim-1 induce the $\mathrm{p} 53$ pathway in cultured cells and correlate with increased Mdm2 in mantle cell lymphoma. J Biol Chem 2008; 283: 18012-18023.

40. Easton JB, Houghton PJ. mTOR and cancer therapy. Oncogene 2006; 25: 6436-6446.

41. Inoki K, Guan KL. Tuberous sclerosis complex, implication from a rare genetic disease to common cancer treatment. Hum Mol Genet 2009; 18: R94-100.

42. Dufner A, Thomas G. Ribosomal $S 6$ kinase signaling and the control of translation. Exp Cell Res 1999; 253: 100-109.

43. Um SH, D'Alessio D, Thomas G. Nutrient overload, insulin resistance, and ribosomal protein S6 kinase 1, S6K1. Cell Metab 2006; 3: 393-402.

44. Reinhard C, Thomas G, Kozma SC. A single gene encodes two isoforms of the p70 S6 kinase: activation upon mitogenic stimulation. Proc Natl Acad Sci USA 1992; 89: 4052-4056.

45. Jaafar R, Zeiller C, Pirola L, Di Grazia A, Naro F, Vidal H et al. Phospholipase D regulates myogenic differentiation through the activation of both mTORC1 and mTORC2 complexes. J Biol Chem 2011; 286: 22609-22621.

46. Kim D, Akcakanat A, Singh G, Sharma C, Meric-Bernstam F. Regulation and localization of ribosomal protein S6 kinase 1 isoforms. Growth Factors 2009; 27: 12-21.

47. Rosner M, Hengstschlager M. Nucleocytoplasmic localization of p70 S6K1, but not of its isoforms p85 and p31, is regulated by TSC2/mTOR. Oncogene 2011; 30: 4509-4522.

48. Bai X, Ma D, Liu A, Shen X, Wang QJ, Liu Y et al. Rheb activates mTOR by antagonizing its endogenous inhibitor, FKBP38. Science 2007; 318: 977-980.

Supplementary Information accompanies the paper on Cell Death and Differentiation website (http://www.nature.com/cdd) 